\author{
Dr. sc. Dario Đerđa, izvanredni profesor \\ Pravnog fakulteta $\mathrm{u}$ Rijeci ${ }^{1}$
}

\title{
PRAVNI OKVIR KORIŠTENJA NEKIH OBLIKA FINANCIJSKE IMOVINE U REPUBLICI HRVATSKOJ
}

\author{
UDK: 342 (497.5) \\ Izvorni znanstveni rad \\ Primljeno: 1. 12. 2016.
}

\begin{abstract}
Cilj je ovoga rada razmotriti jesu li postupci davanja na korištenje nekih nekretnina u državnom vlasništvu zainteresiranim poduzetnicima i drugim subjektima jednostavni i brzi te osiguravaju li oni odabir upravo one osobe koja jamči obavljanje gospodarske djelatnosti najviše kvalitete u okviru standarda održivoga razvoja. U radu se pozornost usmjerava na zemljišta koja se u velikome udjelu nalaze u državnome vlasništvu, a prema ocjeni hrvatske javnosti, nisu u dovoljnoj mjeri iskorištena - poljoprivredno zemljište, šume i šumsko zemljište te javno vodno dobro u javnoj uporabi. Najprije se razmatra jesu li ova zemljišta sposobna biti dijelom financijske imovine države. Zatim se analizira način regulacije i postupovne odredbe davanja ovih dobara na korištenje privatnim osobama. Konačno, ukazuje se na nedostatke pozitivnopravne regulacije te se s ciljem poticanja iskoristivosti ovih prostora daju prijedlozi unapređenja postojećega pravnoga okvira.
\end{abstract}

Ključne riječi: dobro od interesa za Republiku Hrvatsku, poljoprivredno zemljište, šuma, šumsko zemljište, vodno dobro, financijska imovina, korištenje javnoga dobra, Hrvatska

\section{UVOD}

Jedan od najvažnijih ciljeva svake države usmjeren je pružanju visokog životnog standarda svojim stanovnicima. Kako bi ovaj cilj bio ostvaren, građanima na raspolaganju trebaju stajati brojne usluge zdravstvenog, obrazovnog, socijalnog, kulturnog i sportskoga sadržaja, kao i potrebna infrastruktura za prometovanje, odmor i rekreaciju, što u pravilu osigurava država, jedinice područne (regionalne) samouprave i jedinice lokalne samouprave. Veći broj javnih usluga koje građanima nenaplatno ili uz plaćanje određene participacije stoje na raspolaganju u pravilu se financira iz državnog proračuna odnosno proračuna teritorijalnih jedinica, baš kao što se iz tih proračuna financira izgradnja određenih infrastrukturnih objekata. Stoga je jedno od najaktualnijih pravnih, gospodarskih i politoloških pitanja današnjice, na

Izvanredni profesor, predstojnik Katedre za upravno pravo Pravnog fakulteta Sveučilišta u Rijeci. Ovaj rad objavljen je u okviru projekta Hrvatske zaklade za znanost br. 5709, ,,Perspectives of maintaining the social state: towards the transformation of social security systems for individuals in personalized medicine". 
koji način država i druge teritorijalne jedinice, bez dodatnoga poreznoga opterećenja stanovnika i poduzetnika, mogu povećati vlastite prihode.

U tu svrhu državi i drugim teritorijalnim jedinicama na raspolaganju stoje prihodi od dobiti koju ostvaruju trgovačka društva u javnom i mješovitom vlasništvu, kao i prihodi od otuđenja njihove imovine. Pored ovih, jedan od važnih prihoda, kojemu u Hrvatskoj do sada zasigurno nije dovoljno dano na važnosti, svakako čine prihodi od korištenja nekretnina u vlasništvu države. Takve nekretnine kojima upravljaju i gospodare država ili neko drugo tijelo kojemu je povjereno upravljanje, a koje nisu u općoj uporabi, često su sredstvo financiranja javnih potreba u usporednom pravu. Ove površine u državnom vlasništvu, određenim pravnim institutima ustupaju se na korištenje pojedincima, poduzetnicima i drugim subjektima, te time postaju nezaobilazan izvor proračunskih prihoda. Uobičajeno se izdvajaju od drugih dobara od interesa za državu te se posebnim pravnim režimom koji se na njih primjenjuje čine dostupnima pojedincima koji ih žele gospodarski iskorištavati. U pravnoj teoriji u pravilu se nazivaju financijskom imovinom države, jer njihovi korisnici za iskorištavanje ovih prostora državi plaćaju naknadu, koja se zatim koristi u različite svrhe.

U Republici Hrvatskoj posebno do izražaja dolaze tri vrste dobara koja površinom zauzimaju najveći dio prostora državnog teritorija, a u velikoj mjeri upravo su u državnom vlasništvu. ${ }^{2}$ To su poljoprivredno zemljište, šume i šumsko zemljište te vodno dobro. Prema posljednjim službenim podacima iz 2013. godine, poljoprivredne površine u Republici Hrvatskoj zauzimaju čak 47,6 \% zemljišta, gotovo jednako toliko, tj. 47 \% zemljišta zauzimaju šume i šumsko zemljište, vodne površine među koje se ubraja vodno dobro obuhvaćaju 1,6 \% kopnene površine Republike Hrvatske, dok sve preostalo zemljište čine čovjekom utjecane površine, tj. gradovi, sela, industrijska postrojenja, cestovna, željeznička infrastruktura te druge linijske infrastrukturne građevine, zračne luke, vojni objekti i sl. ${ }^{3}$

Od ukupno 2.695.037 ha poljoprivrednih površina u Republici Hrvatskoj, 738.125 ha poljoprivrednog zemljišta, najvećim dijelom oranica i pašnjaka, nalazi se u državnom vlasništvu. Time poljoprivredno zemljište u vlasništvu Republike Hrvatske čini skoro trećinu ukupnoga poljoprivrednoga zemljišta. Od toga je trenutno neiskorišteno gotovo $60 \%$ ovoga zemljišta. ${ }^{4}$ Neobrađeno poljoprivredno zemljište, koje čini zemljište koje nije u funkciji poljoprivredne proizvodnje ili je obraslo višegodišnjim raslinjem, danas je jedan od gorućih problema hrvatske poljoprivrede, posebno u državi bogatih i kvalitetnih prirodnih resursa, tj. zemljišta

O razlikovanju pojma ,,dobro “i „,stvar" više vidi u Popovski, Aleksandra, Upravnopravni aspekti upravljanja i korištenja javnoga dobra u općoj uporabi - doktorska disertacija, Pravni fakultet u Zagrebu, Zagreb, 2016., str. 57-65.

Ministarstvo graditeljstva i prostornoga uređenja, Izvješće o stanju u prostoru Republike Hrvatske 2008.-2012., Narodne novine, br. 61/13. Nakon ovoga dokumenta novije izvješće o stanju u prostoru Republike Hrvatske nije objavljeno niti je o ovome pitanju raspravljano u Hrvatskom saboru. Time se naznačeno izvješće pokazuje najrecentnijim.

4 Posljednje dostupni podaci Agencije za plaćanja u poljoprivredi, iz rujna 2014. godine, dostupno na: http://www.agroklub.com/agropedija/zemljiste/raspolaganje-zemljistem-14// (21. VI. 2016.). 
dobre plodnosti, klimatskih pogodnosti i obilja vodnih resursa. Važnost poljoprivrede za državu u cjelini proizlazi ne samo iz primarne uloge osiguranja prehrambenih potreba stanovništva, već i iz njezine uloge u očuvanju ruralnog prostora, ekološke ravnoteže i održanju tradicijskih vrijednosti. ${ }^{5}$

S druge strane, ukupna površina šuma i šumskih zemljišta u Republici Hrvatskoj iznosi 2.688.687 ha. Od toga je 2.106.917 ha, tj. preko 80 \%, u državnom vlasništvu, dok je 581.770 ha u vlasništvu privatnih šumoposjednika. ${ }^{6}$ Kada se u obzir uzme drvna zaliha u Republici Hrvatskoj, koja se procjenjuje na 398 milijuna m $^{3}$, čak 320 milijuna $\mathrm{m}^{3}$ nalazi se $\mathrm{u}$ državnim šumama, a tek 78 milijuna $\mathrm{m}^{3} \mathrm{u}$ šumama privatnih šumoposjednika. Iz ovih podataka razvidno je kako kapacitet državnih šuma u velikoj mjeri nadmašuje šume privatnih posjednika. Izrazito značajan potencijal šuma i šumskih površina u Hrvatskoj, kao osnovni temelj razvoja, još nije dostatno iskorišten, na što ukazuje veliki udio šumske biomase koji trenutno nije u funkciji. Poboljšano gospodarenje šumama i njihovo korištenje može otvoriti brojna radna mjesta i povećati proizvodnju dobara i usluga, omogućujući time novi dohodak. ${ }^{7}$

Konačno, ukupna duljina svih prirodnih i umjetnih vodotoka na prostoru Republike Hrvatske procjenjuje se na oko $32.000 \mathrm{~km}$, od čega preko 13.000 $\mathrm{km}$ čine vodotoci slivne površine veće od $10 \mathrm{~km}^{2}$. S obzirom na to da je voda jedinstven i nezamjenjiv prirodni resurs ograničenih količina i neravnomjerne prostorne i vremenske raspodjele, kao i činjenica da su svi oblici života i sve ljudske aktivnosti uvijek vezani uz vodu, vodno dobro pokazuje se posebno značajnim. Vodni sektor važan je pokretač gospodarstva, osobito kroz pripremu, izgradnju, opremanje, održavanje i pogon vodnih građevina i sustava, čime znatno pridonosi društveno-gospodarskom razvoju zemlje. Iako Hrvatska ima dovoljno vodnih resursa za zadovoljenje postojećih i potencijalnih potreba korisnika, zbog tehničkih, gospodarskih, okolišnih i političkih čimbenika niti vodni resursi nisu u dovoljnoj mjeri iskorišteni, a na tome bi u budućnosti također valjalo poraditi. ${ }^{8}$

Sve ranije navedeno ukazuje na veliki gospodarski kapital Republike Hrvatske, koji je tek manjim dijelom iskorišten. S ciljem što skorijeg gospodarskog prosperiteta svakako bi valjalo ove važne strateške resurse staviti na raspolaganje gospodarstvenicima. Naravno, cilj koji pri tome svakako treba ostvariti jest uz jednostavne i brze postupke davanja ovih nekretnina na korištenje privatnim poduzetnicima i drugim subjektima, na odgovarajući način zaštititi javni interes

5 Vidi Izvješće o stanju u prostoru Republike Hrvatske 2008.-2012.

6 Sukladno članku 5. točka 24. Zakona o šumama, Narodne novine 140/05, 82/06, 129/08, 80/10, 124/10, 25/12, 68/12, 148/13 i 94/14, šumoposjednik je pravna ili fizička osoba koja je vlasnik ili posjednik šume, osim Republike Hrvatske, trgovačkog društva Hrvatske šume d.o.o., tijela državne uprave i pravnih osoba čiji je osnivač Republika Hrvatska, a koje gospodare šumama u vlasništvu Republike Hrvatske. $\mathrm{O}$ šumama u vlasništvu privatnih osoba, pretvorbi prava vlasništva i upisu šuma i šumskih zemljišta u zemljišne knjige više vidi u Perkušić, Ante, ,Šume i šumska zemljišta - pretvorba prava vlasništva i upis u zemljišne knjige“, Hrvatska pravna revija, god. 4., br. 11, 2004., str. 51-56.

7 Vidi Izvješće o stanju u prostoru Republike Hrvatske 2008.-2012.

8 Vidi Izvješće o stanju u prostoru Republike Hrvatske 2008.-2012. 
i održivost ovih, u svjetskim razmjerima oskudnih resursa. ${ }^{9}$ Cilj je ovoga rada razmotriti jesu li postupci davanja na korištenje nekih nekretnina u državnom vlasništvu zainteresiranim poduzetnicima i drugim subjektima jednostavni i brzi te osiguravaju li oni odabir upravo one osobe koja jamči obavljanje gospodarske djelatnosti najviše kvalitete u okviru standarda održivoga razvoja. U radu se pozornost usmjerava na zemljišta koja se u velikome udjelu nalaze u državnome vlasništvu, a prema ocjeni hrvatske javnosti, nisu u dovoljnoj mjeri iskorištena. Najprije se razmatra jesu li ova zemljišta sposobna biti dijelom financijske imovine države. Zatim se analizira način regulacije i postupovne odredbe davanja ovih dobara na korištenje privatnim osobama. Konačno, ukazuje se na nedostatke pozitivnopravne regulacije te se s ciljem poticanja iskoristivosti ovih prostora daju prijedlozi unapređenja postojećega pravnoga okvira.

\section{POLJOPRIVREDNO ZEMLJIŠTE, ŠUME I ŠUMSKO ZEMLJIŠTE TE VODNO DOBRO U VLASNIŠTVU DRŽAVE KAO OBLICI FINANCIJSKE IMOVINE}

Financijska je imovina pojam koji se ne susreće u hrvatskom zakonodavstvu, već jedino u znanstvenoj i stručnoj literaturi. Ovaj pojam javlja se u radovima Krbeka 50-ih godina 20. stoljeća i poslije, koji financijsku imovinu, ujedno nazivajući je i financijskim dobrom odnosno fiskalnom imovinom, stavlja u opreku s drugim stvarima koje su od interesa za zajednicu, tj. s javnim dobrom ili dobrom opće upotrebe te upravnim dobrom ili upravnom imovinom. Navodeći kako javno dobro podrazumijeva ona dobra koja neposredno služe svim građanima a da im se posebno ne predaju na korištenje, a upravno dobro stvari koje služe osobama javnoga prava za trajno obavljanje zadaća javne uprave, bilo da se upravna tijela njima služe neposredno, bilo da ih naročitom predajom stavljaju na uporabu građanima, npr. posredstvom bolnica, škola ili biblioteka, financijsku imovinu Krbek detaljnije ne obrazlaže već samo ističe kako je njezina primarna svrha donošenje financijskih sredstava državi. ${ }^{10}$

9 Iako nema mnogo radova koji znanstveno i stručno analiziraju mehanizme korištenja ovih dobara, u hrvatskoj pravnoj literaturi posljednjih desetak godina sve se češće naglašava potreba učinkovitijega upravljanja njima. Tako primjerice Frković ističe kako bi osnivanje prava građenja na nekretninama $u$ vlasništvu Republike Hrvatske moglo biti atraktivan pravni institut i model za stimuliranje investicija, jer temeljem ovoga pravnoga instituta, država nekretnine zadržava u vlasništvu i ubire obročnu rentu, a investitor, umjesto isplate tržišne cijene odjednom u slučaju sklapanja ugovora o prodaji, ima manje teretne financijske obveze, a ipak je vlasnik zgrade izgrađene na državnom zemljištu. Frković, Snježana, „Republika Hrvatska kao vlasnik nekretnina i pravo građenja“, Hrvatska pravna revija, god. 11., br. 10, 2011., str. 10. O potrebi učinkovitijeg upravljanja ovim resursima vidi i Grubišić, Mihaela, Nušinović, Mustafa, Roje, Gorana, „Prema učinkovitom upravljanju državnom imovinom“, Financijska teorija $i$ praksa, vol. 33, br. 3, 2009., str. 335-374.

10 Krbek, Ivo, Osnovi upravnog prava FNRJ, Jugoslavenska akademija znanosti i umjetnosti, Zagreb, 1950., str. 507, te Krbek, Ivo, Pravo jugoslavenske javne uprave: funkcioniranje i upravni spor, III. knjiga, Birozavod, Zagreb, 1962., str. 120. 
Krbekovu podjelu stvari kojima se služi država ili neka druga osoba javnoga prava u pravnoj literaturi slijede Aviani i Josipović. Na isti način, oni financijsku imovinu razlikuju od javnih dobara u općoj uporabi, tj. stvari u vlasništvu Republike Hrvatske ili drugih osoba javnoga prava koje su namijenjene za uporabu svih, te javnih dobara u javnoj uporabi, tj. stvari u vlasništvu Republike Hrvatske ili drugih osoba javnoga prava koje su namijenjene neposrednom izvršavanju prava i dužnosti Republike Hrvatske, njezinih tijela i ustanova. Naglašavaju kako stvari u vlasništvu Republike Hrvatske ili druge osobe javnoga prava koje čine financijsku imovinu nisu namijenjene ni općoj ni javnoj uporabi, već isključivo ostvarivanju prihoda njihovim vlasnicima. ${ }^{11}$

Iako se u različitim državama naziva različitim nazivima, financijska imovina široko je usvojen institut u usporednom pravu. $U$ austrijskoj pravnoj doktrini javne stvari, tj. stvari koje se nalaze u vlasništvu osoba javnog prava, konkretno savezne države, federalne jedinice ili jedinice lokalne samouprave i koje su namijenjene obavljanju javnih zadaća, također se dijele na javno dobro i upravnu imovinu te financijsku imovinu koja predstavlja stvari u vlasništvu osoba javnoga prava, tj. savezne države, federalne jedinice ili jedinice lokalne samouprave, a čija je svrha ostvarivanje financijskih prihoda njihovim vlasnicima. U ovoj državi financijsku imovinu čine šume, vrijednosni papiri ili dionice, udjeli u temeljnom kapitalu trgovačkih društava i sl. ${ }^{12}$ Financijska imovina kao pravni institut važno mjesto našla je i u njemačkoj pravnoj doktrini gdje se dobra od javnoga interesa dijele u dvije velike skupine: javne stvari i financijsku imovinu. Financijsku imovinu čine stvari koje se nalaze u vlasništvu osoba javnoga prava, a istovremeno nisu namijenjene neposrednom korištenju od strane društvene zajednice niti obavljanju zadaća tijela javne vlasti. Njome raspolažu osobe javnoga prava te su financijske koristi od raspolaganja takvom imovinom izravan prihod proračuna ovih osoba. Slijedom toga, osnovna svrha financijske imovine u Njemačkoj ista je kao i u Austriji - ostvarivanje financijskih prihoda njihovim vlasnicima, neovisno o tome radi li se o državi ili jedinici regionalne ili lokalne samouprave. Financijsku imovinu u Njemačkoj čine, primjerice, šume i poljoprivredna zemljišta, trgovačka društva,

11 Aviani, Damir, „Zasebno korištenje opće-uporabljivih dobra u Hrvatskoj: dometi i ograničenja“, Zbornik radova Pravnog fakulteta u Splitu, god. 46, br. 1, 2009., str. 125, Josipović, Tatjana, „Posebni pravni režimi na nekretninama“, Nekretnine u pravnom prometu, Inženjerski biro, Zagreb, 2003., str. 4. te Josipović, Tatjana, „Stvari u vlasništvu države i drugih osoba javnog prava (javno vlasništvo)“, Zbornik Pravnog fakulteta Sveučilišta u Rijeci, vol. 22, br. 1, 2001., str. 100. Istu klasifikaciju javnih stvari od Josipović je preuzela Jelčić u: Jelčić, Olga, „Prodaja, zakup i koncesije nekretnina u vlasništvu jedinica lokalne samouprave i Republike Hrvatske", 12. forum poslovanja nekretninama: zbornik radova, Zagreb, Hrvatska gospodarska komora, 2012., dostupno na: http://www.agenti.hr/sadrzaj/info-agent/strukovniforumi/forum-12/12-forum-Prodaja-zakup-koncesije-nekretnina-vlasnistvo-jed-lokalne-samouprave-iRH.pdf (11. VII. 2016.), str. 7-8.

12 Javno dobro u Austriji obuhvaća dobra u vlasništvu osoba javnog prava namijenjena općoj uporabi, kao što su npr. ceste, rijeke, potoci, jezera, luke, javne površine i sl., a upravnu imovinu ona dobra i stvari namijenjeni obavljanju zadaća javne uprave poput javnih bolnica, vojarni, javnih škola, knjižnica, muzeja i zgrada upravnih tijela, uredski inventar i materijal i sl. Vidi Antoniolli, Walter, Koja, Friedrich, Allgemeines Verwaltungsrecht, Manzsche Verlags- und Universitätsbuchhandlung, Wien, 1996., str. 697699. O javnom vlasništvu u austrijskom pravu više vidi u Popovski, op. cit., str. 33-36. 
vrijednosni papiri itd. ${ }^{13}$ Iako se u francuskoj pravnoj teoriji pojam financijska imovina ne susreće, odgovarajući institut ovdje se može prepoznati pod nazivom privatna domena. Stvari u vlasništvu osoba javnoga prava u ovoj državi dijele se na javnu i privatnu domenu. Privatna domena obuhvaća dobra i stvari koje su podložne vlasničkom režimu i vršenju vlasničkih prava osoba javnoga prava. Kako se u pravnoj teoriji ističe, jedna od namjena ovih dobara upravo je stvaranje financijskih prihoda koji će se zatim kroz financiranje javnih službi vratiti građanima. U privatnu domenu ubrajaju se šume i poljoprivredno zemljište u vlasništvu osoba javnoga prava, napuštena riječna korita, ruralne ceste i nekretnine kojima je ukinut status ceste ili željezničke infrastrukture, nekretnine koje koristi država te regionalna i lokalna samouprava, nekretnine koje su osobe javnoga prava stekle izvlaštenjem, konfiskacijom ili nacionalizacijom, ošasna imovina, državni brodovi i zrakoplovi, prava intelektualnog vlasništva osoba javnoga prava, vojna oprema te pravo lova uključujući ribolovna prava. ${ }^{14}$ Time određena dobra iz kategorije privatne domene u Francuskoj imaju sličnu funkciju koju financijska imovina ima u austrijskom i njemačkom pravu. U talijanskom pravu javne stvari se također dijele u dvije velike skupine: domanijalna dobra i baštinu. Dobra čija je namjena između ostaloga

13 Njemačka pravna teorija javne stvari još dijeli na javne stvari u eksternoj upotrebi i javne stvari u internoj upotrebi. Javne stvari u eksternoj upotrebi obuhvaćaju neke stvari koje su u općoj uporabi svih građana, tj. stvari koje su dane na ravnopravnu i slobodnu uporabu svima kao što su npr. more i morska obala, plovne rijeke, ceste, javne površine i zračni prostor iznad državnoga teritorija. One ujedno obuhvaćaju i neke stvari koje su zbog pojedinačne potrebe koja nadilazi opću dane u posebnu upotrebu nekom konkretnom pojedincu, kao i stvari koje građani upotrebljavaju posredstvom pružatelja javnih usluga uživajući usluge koje pruža određeni nositelj javne službe, kao što su npr. javne bolnice, javna kupališta, narodna kazališta i knjižnice. Za razliku od ovih, javne stvari u internoj uporabi nisu dane na uporabu svim osobama, već ih za ostvarivanje svojih zadaća koriste isključivo tijela javne vlasti. U ovu skupinu spadaju između ostaloga zgrade državnih i lokalnih upravnih tijela, uredski namještaj, policijska, vojna i vatrogasna oprema i službena vozila. Papier, Hans Jürgen, Recht der Öffentlichen Sachen, Walter de Gruyter, Berlin, 1977., str. 15-19. i 33. Virant, Gregor, „Pravni položaj uporabnika javnega dobra“, Pravnik, vol. 50, br. 9-10, 1995., str. 28. Iako u Njemačkoj pravna doktrina sistematizira dobra od javnoga interesa u dvije, a ne tri kategorije kakav je slučaj u Austriji, dobrima od javnoga interesa smatraju se iste stvari. O javnoj imovini u Njemačkoj više vidi u $35 . \quad$ Gröpl, Christoph, Rupp, Martin, „State Assets (Public Ownership) in the Federal Republic of Germany", Ius Publicum Network Review, br. 1, 2011., dostupno na: http://www.ius-publicum.com/repository/uploads/10_03_2011_16_33_Groepl.pdf (11. VII. 2016.), str. 1-7. te Popovski, op. cit., str. 29-33.

14 Auby, Jean-Marie, Bonn, Pierre, Droit administratif des biens, Dalloz, Paris, 1995., str. 163-170. Javnu domenu u Francuskoj čine npr. teritorijalno more i njegovo podmorje te dno, dio obale koju more prekrije za vrijeme najviših voda, plaže, luke, zaljevi i objekti izgrađeni u interesu pomorskog prometa, rijeke namijenjene plovidbi, vodoopskrbi, poljoprivrednoj i industrijskoj djelatnosti, plovna jezera, kanali, akumulacije te građevine namijenjene održavanju vodnog režima i regulaciji plovidbe, zračni prostor iznad državnog teritorija i zračne luke namijenjene javnom prometu, radijske frekvencije dostupne na državnom teritoriju, ceste, željeznička infrastruktura, javne površine, vojno dobro, sakralne građevine, telekomunikacijska infrastruktura, zgrade sudova, kulturna i umjetnička dobra, knjižni fond, arhivsko gradivo i druge pokretnine koje su nezamjenjive ili teško zamjenjive, spomenici, javne bolnice, javne škole, narodne knjižnice, muzeji, groblja, tržnice i studentski domovi. Kako bi se neko dobro smatralo javnom domenom, ono mora biti u vlasništvu osobe javnoga prava, tj. države, jedinice regionalne samouprave, jedinice lokalne samouprave ili javne institucije pod kojim se pojmom podrazumijevaju ustanove, javne ustanove i određene vrste trgovačkih društava. Vidi ibid., str. 29-42. O javnom vlasništvu u francuskom pravu više vidi u: Latournerie, Marie-Aimée, „Problématique du droit des propriétés publiques en France“, Zbornik radova Pravnog fakulteta u Splitu, god. 46, br. 1, 2009., str. 11-25, Borković, Ivo, „Javno dobro (domaine public) u francuskoj teoriji upravnog prava“, Zbornik radova Pravnog fakulteta u Splitu, god. 40, br. 71-72, 2003., str. 219-232 te Popovski, op. cit., str. 14-20. 
ostvarivanje financijskih prihoda njihovim vlasnicima nazivaju se baštinom. Dijele se na dvije kategorije: baštinu izvan pravnog prometa i baštinu u pravnom prometu. Baštinu izvan pravnog prometa čine dobra koja su u vlasništvu osoba javnog prava te su od značaja za javni interes poput šuma, mineralnih sirovina, termalnih i mineralnih izvora vode, zgrada tijela javne vlasti, nekretnina i pokretnina koje služe obavljanju javnih službi, nekretnina koje su bile predmet izvlaštenja, nacionalnih parkova, parkova prirode, prirodnih rezervata, vojarni, vojnih brodova i zrakoplova te divljih životinja, dok baštinu u pravnom prometu čine npr. trgovačka društva i vrijednosni papiri u vlasništtvu osoba javnog prava. ${ }^{15}$

Može se uočiti kako se u austrijskom, njemačkom, francuskom i talijanskom pravu izdvaja posebna skupina dobara koja su u vlasništvu osoba javnoga prava, tj. savezne države, saveznih jedinica, regionalne ili područne samouprave i kojima je namjena, između ostaloga, ostvarivanje prihoda njihovim vlasnicima. Ova dobra, bez obzira na to nazivaju li se „financijskom imovinom“, „privatnom domenom“ ili „baštinom“, nalaze se u posebnom pravnom režimu koji nije u cijelosti uređen pravnim normama javnoga tj. upravnoga prava, ali nije u cijelosti uređen niti pravnim normama građanskoga prava koje se primjenjuju na vlasništvo privatnih osoba.

Tako je, primjerice, financijska imovina u Austriji u velikoj mjeri uređena pravilima građanskoga, a u manjoj pravilima upravnoga prava. Propisanim upravnopravnim ograničenjima slobodnoga raspolaganja ovom imovinom štiti se javni interes koji bi mogao biti povrijeđen kada bi se ova dobra uređivala isključivo normama građanskoga prava. ${ }^{16}$ Slično je i u Njemačkoj u kojoj se gospodarenje financijskom imovinom temelji na normama građanskoga prava, uz određena ograničenja javnopravne naravi. No, upravo poradi ovih ograničenja, osobe javnoga prava prilikom raspolaganja financijskom imovinom obvezne su računa voditi o javnome interesu. ${ }^{17}$ I u Francuskoj je privatna domena u prvome redu uređena

15 Vidi Virant, op. cit., str. 34-36. U domanijalna dobra ubrajaju se npr. more i morska obala, rijeke, jezera, podzemne vode, ceste, željeznička infrastruktura, vojni objekti, javne površine, groblja, zračni prostor iznad državnog teritorija, zračne luke te kulturni spomenici. Ova dobra također mogu biti jedino u vlasništvu osobe javnoga prava, tj. države, regije, provincije ili komune te moraju imati zakonom određenu javnu namjenu koja se ogleda u njihovom davanju na slobodnu uporabu građanima ili njihovom korištenju od pružatelja javnih usluga za izvršavanje njihovih zadaća. Vidi Caringella, Francesco, Il Diritto Amministrativo, Edizioni giuridiche Simone, Napoli, 2006., str. 907. O javnom vlasništvu u talijanskom pravu više vidi u Popovski, op. cit., str. 21-24.

16 Za razliku od ovih dobara, javno dobro u općoj uporabi u Austriji regulirano je normama upravnoga prava, a zaštita javnoga interesa u svezi s njime posebno je osigurana zabranom privatnopravnih raspolaganja tim dobrima koja bi na bilo koji način mogla ograničiti ili isključiti opću uporabu. Pravni režim upravne imovine uglavnom je uređen normama upravnoga prava, uz odgovarajuću primjenu i pravnih normi građanskoga prava. Cilj takvome pravnom uređenju ogleda se u unapređenju i očuvanju javne namjene ovih dobara i stvari. Antoniolli, Koja, op. cit., str. 697-698.

17 Vidi Virant, op. cit., str. 29. te Borković, Upravno pravo, Narodne novine, Zagreb, 2002., str. 589. Za razliku od austrijskoga prava, pravni režim dobara od javnoga interesa u Njemačkoj uređen je pravnim normama kako javnoga tako i privatnoga prava. Međutim, ističe se kako učinak normi javnoga prava ipak prevladava. Javni interes zaštićen je u prvom redu zabranom privatnim osobama raspolagati javnom stvari na svaki način kojim se ograničava ili isključuje opća uporaba takve stvari. Vlasnik neke od stvari koja se nalazi u općoj uporabi pri izvršavanju vlasničkih ovlasti ograničen je onoliko koliko je potrebno 
normama građanskog prava. Njome upravljaju osobe javnog prava, ali također uz značajna ograničenja upravnopravne prirode. ${ }^{18}$ Konačno, norme građanskoga prava, jednako tako uz prilična upravnopravna ograničenja usmjerena na zaštitu javnoga interesa, u Italiji se primjenjuju na baštinu u pravnom prometu. ${ }^{19} \mathrm{Iz}$ ovoga jasno proizlazi kako se u spomenutim državama na financijsku imovinu primjenjuje pravni režim građanskoga prava, u nekim pitanjima ograničen normama upravnoga prava.

Dade se primijetiti kako u prikazanim usporednim pravnim sustavima, uz dobra koja stoje na raspolaganju građanima i koja oni neposredno ili posredno koriste sukladno načelu slobode, ravnopravnosti i anonimnosti, te uz dobra koja su namijenjena obavljanju zadaća koje su ustavom i zakonima stavljene u nadležnost osobama javnoga prava, postoje još i dobra koja se nalaze u vlasništvu osoba javnoga prava, a nisu namijenjena niti općoj uporabi niti izvršavanju javnih zadaća osoba javnoga prava. U analiziranim pravnim sustavima njih, između ostaloga, čine i zemljišta u vlasništvu države i drugih osoba javnoga prava, među kojima se nalaze poljoprivredna zemljišta, šume i šumska zemljišta te neke druge vrste zemljišta. Njihova namjena usmjerena je stjecanju financijskih prihoda osoba javnoga prava u čijem su vlasništvu. Za razliku od prve dvije skupine dobara, koja se u bitnome nalaze ili u vlasništvu osoba javnoga prava ili izvan vlasničkoga režima te su poradi očuvanja svoje namjene uređena u prvom redu pravnim normama upravnoga prava, na ova dobra primjenjuje se primarno pravni režim građanskoga prava, koji je u određenoj mjeri podređen nekim pravnim normama upravnoga prava. ${ }^{20}$ Posebno pravno uređenje ovih dobara uspostavlja se s obzirom na ulogu i namjenu tih dobara u društvenoj zajednici ili gospodarskoj infrastrukturi. Upravnopravna ograničenja vršenja vlasničkih ovlasti pojedinih dobra od interesa za zajednicu uvode se radi postizanja i zaštite općih interesa, tj. interesa društva kao cjeline, a posredstvom toga i interesa samih članova društva odnosno pojedinaca. Međutim, djelovanje

da bi ta stvar služila javnoj svrsi kojoj je namijenjena. Vidi Wolff, Hans J., Bachof, Otto, Stober, Rolf, Verwaltungsrecht, Band 2, Verlag C. H. Beck, München, 2000., str. 679.

18 Vidi Auby, Bon, op. cit., str. 134. te Borković, Upravno, cit., str. 588. Za razliku od privatne domene, u Francuskoj je zaštita javne domene usmjerena prvenstveno na očuvanje njezine javne namjene. Ona je uređena pravilima upravnoga prava koja zabranjuju njezino otuđenje, provedbu prisilnog izvršenja nad ovim dobrima te zabranu stjecanja ovih dobara dosjelošću. Vidi Gillet-Lorenzi, Emmanuelle, Traoré, Seydou, Droit administratif des biens, Centre National de la Fonction Publique Territoriale, Paris, 2007. str. 70-77. te Borković, Upravno, cit., str. 586-587.

19 Domanijalna dobra u Italiji uređena su pravilima upravnoga prava te su zaštićena općom zabranom njihova otuđenja, zabranom prisilnog izvršenja nad ovim dobrima te zabranom stjecanja vlasništva nad ovim dobrima dosjelošću. Kako bi se što bolje zaštitila i očuvala javna namjena domanijalnih dobara, ona su u cijelosti isključena iz pravnoga prometa. Vidi Caringella, op. cit., str. 907. Sličan pravni režim javnoga dobra u usporednome pravu susreće se primjerice i u Sloveniji. O tome više u Ude, Lojze, ,Javno dobro“, Socijalno partnerstvo, vol. 22, br. 168-169, 1994., str. 133-134.

20 O primjeni normi upravnoga i građanskoga prava na stvari u vlasništvu osoba javnoga prava više vidi u: Negrut, Vasilica, ,, Special Domenial Regimes“, Acta Universitatis Danubius: Juridica, vol. 5, br. 1, 2009., dostupno na: http://journals.univ-danubius.ro/index.php/juridica/article/view/186/177 (11. VII. 2016.), str. 40-47. 
Dr. sc. Dario Đerđa: Pravni okvir korištenja nekih oblika financijske imovine u Republici Hrvatskoj Zbornik radova Pravnog fakulteta u Splitu, god. 54, 1/2017., str. 121.-158.

upravnopravnih normi nužno ne isključuje norme građanskoga prava, već ih ujedno i nadopunjuje. $^{21}$

Za razliku od ovih država, hrvatsko zakonodavstvo ne poznaje pojam financijske imovine. Zakon o vlasništvu i drugim stvarnim pravima razlikuje tri vida stvari, koje dijeli prema njihovoj namjeni. Propisuje kako javno dobro u općoj uporabi čine stvari u vlasništvu Republike Hrvatske koje su namijenjene za uporabu svih te kako se ovim stvarima ima pravo služiti svatko na način koji su radi ostvarenja te namjene odredili tijelo ili ustanova kojoj su dane na upravljanje, odnosno tijelo nadležno za određivanje namjene, koje njima neposredno upravlja. Pored ovih stvari, Zakon još razlikuje javna dobra u javnoj uporabi, tj. stvari u vlasništvu Republike Hrvatske koje su namijenjene neposrednom izvršavanju prava i dužnosti Republike Hrvatske, njezinih tijela i ustanova, a koje ova tijela i ustanove u skladu s tom namjenom rabe. Konačno, ovaj Zakon identificira još jednu vrstu stvari, tzv. stvari koje su u vlasništvu Republike Hrvatske, a koje nisu namijenjene ni za opću niti za javnu uporabu. Propisuje kako vlasnička prava nad ovim stvarima izvršava tijelo nadležno za određivanje njihove namjene, ako to nije povjerilo kojem drugom tijelu, ustanovi ili osobi, a čisti prihod od tih stvari prihod je državnoga proračuna. ${ }^{22}$ Josipović ističe kako se na ovu posljednju kategoriju stvari u najvećem opsegu primjenjuje opće stvarnopravno uređenje, iako je dopušteno da se za njih posebnim zakonima utvrde posebni pravni režimi. ${ }^{23}$ Može se zaključiti da upravo ove stvari imaju funkciju financijske imovine, kako se ona shvaća u usporednome pravu. Međutim, niti Zakonom o vlasništvu i drugim stvarnim pravima, niti zakonima koji uređuju posebna upravna područja, nije jasno propisano koje specifično dobro predstavlja takvu stvar. Stoga se u određivanju financijske imovine u Hrvatskoj treba poslužiti razgraničenjem onih stvari koje jesu u vlasništvu Republike Hrvatske, a pri tome nisu u općoj uporabi niti služe za obavljanje javnih zadaća i funkcija.

Javno dobro u općoj uporabi u Hrvatskoj čine ceste, željeznička infrastruktura te neki dijelovi javnoga vodnoga dobra. Unatoč činjenici da se ova dobra nalaze u vlasničkom režimu, svim je osobama zakonom zajamčeno pravo njihove uporabe. ${ }^{24}$

21 U korist javnopravne metode uređivanja pravnih odnosa na nekretninama od interesa za državu govori i Gavella, naglašavajući kako je javnopravna metoda ponekad potrebna da bi se adekvatno zaštitili i ostvarivali opći i javni interesi. Međutim, on ujedno upozorava kako ova metoda nije bez nedostataka, jer sobom nosi opasnost od birokratskog postupanja i nedovoljno elastičnoga djelovanja, ali i od različitih zloupotreba. Privatnopravna metoda stvaranja prava i kreiranja pravnih odnosa, prema njegovu je mišljenju kao demokratska suprotstavljena autoritarnoj metodi kojom se služi javno pravo. No, ističe kako ni provatnopravna metoda nije bez nedostataka, jer ona pogoduje slobodi pojedinca u društvenim odnosima, a također može biti zlorabljena s teškim posljedicama za pojedince i društvo. Gavella, Nikola, „O posebnim pravnim uređenjima za pojedine vrste stvari kao sastavnim dijelovima stvarnopravnog uređenja“, Stvarno pravo - posebna pravna uređenja, Narodne novine, Zagreb, 2011., str. 6.

22 Članak 35. stavci 4. do 6. Zakona o vlasništvu i drugim stvarnim pravima, Narodne novine, br. 91/96, 68/98, 137/99, 22/00, 73/00, 114/01, 79/06, 141/06, 146/08, 38/09, 153/09, 90/10, 143/12 i 152/14.

23 Vidi Josipović, Stvari, cit., str. 103.

24 Člankom 3. stavak 1. Zakona o cestama, Narodne novine, br. 84/11., 22/13., 54/13., 148/13. i 92/14., utvrđeno kako su javne ceste javno dobro u općoj uporabi u vlasništvu Republike Hrvatske. Člankom 4. točkom 42. Zakona o željeznici, Narodne novine, br. 94/13. i 148/13., propisano je kako je željeznička infrastruktura javno dobro u općoj uporabi u vlasništvu Republike Hrvatske kojeg mogu koristiti svi zainteresirani željeznički prijevoznici, uz jednake uvjete, na način propisan tim Zakonom. 
S druge strane, javno dobro u javnoj uporabi zakonom nije izričito utvrđeno. U provedbenom konceptu ono predstavlja stvari u vlasništvu Republike Hrvatske ili drugih javnopravnih tijela koje su namijenjene neposrednom izvršavanju prava i dužnosti Republike Hrvatske, njezinih tijela i ustanova. Dakle, bitno obilježje ove imovine pored vlasništva svakako predstavlja i namjena. Slijedom toga, ove stvari moraju služiti obavljanju državnih funkcija i nadležnosti. Tako se primjerice u ovu imovinu ubrajaju javne bolnice, javne škole, knjižnice, studentski domovi, muzeji, vojarne, zgrade državnih, regionalnih i lokalnih upravnih tijela, uredski namještaj i materijal, policijska, vojna i vatrogasna oprema i službena vozila i sl. Dobra koja nisu niti u općoj niti u javnoj uporabi smatraju se financijskom imovinom, a koja je primarno namijenjena ostvarivanju prihoda njihovim vlasnicima. Financijskom imovinom u Hrvatskoj se svakako mogu smatrati poljoprivredno zemljište u vlasništvu države, šume i šumsko zemljište u vlasništvu države te dijelovi javnog vodnoga dobra. Ova dobra ne koriste se za obavljanje funkcija i drugih zadaća iz nadležnosti države, a mogu biti izvor prihoda koji se ostvaruju od ustupanja ovih dobara na korištenje privatnim osobama.

Na stvari u vlasništvu države i drugih osoba javnog prava u Hrvatskoj se primjenjuju ista pravila kao na stvari u vlasništvu fizičkih osoba i pravnih osoba privatnoga prava, osim ako zakonom koji uređuje posebno upravno područje nije određeno drugačije. To znači da kao vlasnik Republika Hrvatska i druge osobe javnog prava imaju jednak položaj kao i svaka privatna osoba. Ovo proizlazi iz pravne prirode vlasništva u Hrvatskoj koje je jednovrsno, odnosno jedno i jedinstveno. Međutim, korištenje ovih dobra zakonom je uvjetovano posebnim odobrenjem javnopravnog tijela, koje može biti u obliku upravnoga akta, koncesije, ugovora i sl. ${ }^{25}$ Stoga se na poljoprivredno zemljište u vlasništvu države, šume i šumsko zemljište u vlasništvu države te na javno vodno dobro u javnoj uporabi, primjenjuje pravni režim građanskoga prava, osim kada je pravnim normama upravnoga prava propisano drukčije.

Poljoprivrednim zemljištem u Republici Hrvatskoj smatraju se poljoprivredne površine i to oranice, vrtovi, livade, pašnjaci, voćnjaci, maslinici, vinogradi, ribnjaci, trstici i močvare, te drugo zemljište koje se uz gospodarski opravdane troškove može privesti poljoprivrednoj proizvodnji, baš kao i neobraslo šumsko zemljište i zemljište obraslo početnim ili degradacijskim razvojnim stadijima šumskih sastojina, kao što su makija, garig, šikare, šibljaci i drugo, a pogodno je za poljoprivrednu proizvodnju. ${ }^{26}$ Zakonom o poljoprivrednom zemljištu propisano je

Člankom 11. stavak 4. Zakona o vodama, Narodne novine, br. 153/09., 63/11., 130/11., 56/13. i 14/14., utvrđeno je kako je javno vodno dobro javno dobro u općoj uporabi odnosno u javnoj uporabi i kako je ono u vlasništvu Republike Hrvatske. Naravno, neka od ovih dobara korisnici koriste neposredno, kao npr. ceste, dok druge koriste posredno putem pružatelja usluga, kao npr. željezničku infrastrukturu u željezničkom prijevozu.

25 O ovome više vidi u Aviani, op. cit., str. 123. i Josipović, „Stvari“, cit., str. 96.

26 Članak 3. stavci 2. i 3. Zakona o poljoprivrednom zemljištu, Narodne novine, br. 39/13 i 48/15, Belaj ističe kako poljoprivredno zemljište u Hrvatskoj predstavljaju nekretnine kojima je bitni dio zemljište koje je poljoprivredno, bilo prema pravnom, bilo prema faktičnom kriteriju. Prema pravnom kriteriju, poljoprivredna zemljišta su ona koja su dokumentima prostornoga uređenja određena kao poljoprivredna 
kako je poljoprivredno zemljište dobro od interesa za Republiku Hrvatsku te ima osobitu zaštitu države. ${ }^{27}$ Zaštita državnoga interesa na poljoprivrednome zemljištu posebno se ogleda u obvezama održavanja ovoga zemljišta u stanju pogodnom za poljoprivrednu proizvodnju. ${ }^{28}$ Iako je poljoprivredno zemljište u velikom dijelu u vlasništvu privatnih osoba, postoje strogi uvjeti za stjecanje vlasništva nad ovim zemljištem. ${ }^{29}$ Da se poljoprivredno zemljište u vlasništvu države treba smatrati vidom financijske imovine, jasno proizlazi iz namjene prihoda koji se ostvaruju zakupom poljoprivrednoga zemljišta i ribnjaka te davanjem ovoga zemljišta na korištenje bez javnog poziva. Prihod ostvaren po ovim osnovama prihod je javnih proračuna i dijeli se između države, jedinice područne (regionalne) samouprave i jedinice lokalne samouprave na čijem se području poljoprivredno zemljište nalazi. ${ }^{30}$

Šumom se smatra zemljište obraslo šumskim drvećem u obliku sastojine na površini većoj od 10 ari, šumski rasadnici i sjemenske plantaže koje su sastavni dio šume, šumska infrastruktura, protupožarni prosjeci te ostala manja otvorena područja unutar šume, šume u zaštićenim područjima prema posebnom propisu, šume od posebnoga ekološkoga, znanstvenoga, povijesnog ili duhovnog interesa, vjetrobrani i zaštitne zone - zaštitni pojasevi drveća površine veće od 10 ari i širine veće od 20 m. Šumskim zemljištem smatra se zemljište na kojem se uzgaja šuma ili koje je zbog svojih prirodnih obilježja i uvjeta gospodarenja predviđeno kao najpovoljnije za uzgajanje šuma. Zakonom o šumama utvrđeno je da su šume i šumska zemljišta

zemljišta, pa je za njih u katastru nekretnina navedena vrsta uporabe koja odgovara poljoprivrednoj namjeni, dok prema faktičnom kriteriju poljoprivredna zemljišta čine ona koja su u upotrebi kao oranice, vrtovi, livade, pašnjaci, voćnjaci, maslinici, vinogradi, ribnjaci, trstici i močvare. Belaj, Vlado, „Posebno stvarnopravno uređenje za poljoprivredna zemljišta“", Stvarno pravo - posebna stvarna uređenja, Narodne novine, Zagreb, 2011., str. 103-104.

27 Članak 2. stavak 1. Zakona o poljoprivrednom zemljištu. Razlog tome svakako je važnost namjene ovoga zemljišta za poljoprivrednu proizvodnju, tj. proizvodnju hrane, što je nesumnjivo od vitalnog značaja za državu i njezino stanovništvo. Vidi ibid., str. 105.

28 Tako je člankom 4. stavci 1., 2. i 4. Zakona o poljoprivrednom zemljištu propisano kako se treba spriječiti zakorovljenost i obrastanje poljoprivrednoga zemljišta višegodišnjim raslinjem te voditi računa da ne dođe do smanjenja njegove plodnosti. U tu svrhu vlasnici i posjednici ovoga zemljišta obvezni su obrađivati poljoprivredno zemljište primjenjujući potrebne agrotehničke mjere, ne umanjujući njegovu vrijednost.

29 Sukladno članku 2. stavci 2. i 3. Zakona o poljoprivrednom zemljištu, vlasništvo nad poljoprivrednim zemljištem ne mogu stjecati strane pravne i fizičke osobe, osim ako međunarodnim ugovorom i posebnim propisom nije drugačije određeno. Strane pravne i fizičke osobe mogu steći pravo vlasništva na poljoprivrednom zemljištu jedino nasljeđivanjem.

30 Sukladno članku 44. stavci 1. do 3. Zakona o poljoprivrednom zemljištu ova sredstva koja su prihod jedinica lokalne i područne (regionalne) samouprave namijenjena su isključivo za programe katastarsko-geodetske izmjere zemljišta, sređivanja zemljišnih knjiga, za podmirenje dijela stvarnih troškova u vezi s provedbom toga Zakona, za program razminiranja zemljišta, program uređenja ruralnog prostora izgradnjom i održavanjem ruralne infrastrukture vezane za poljoprivredu i akvakulturu, za program uređenja zemljišta u postupku komasacije i hidromelioracije, program očuvanja ugroženih područja i očuvanja biološke raznolikosti i program sufinanciranja i druge poticajne mjere za unapređenje poljoprivrede i akvakulture. Osim ovih namjena, sredstva koja su prihod jedinica lokalne samouprave mogu se koristiti i za sufinanciranje aktivnosti izrade programa, projekata i ostalih dokumenata neophodnih za provedbu mjera potpore iz Programa ruralnog razvoja kod kojih se izrada ne sufinancira kroz mjere potpore iz toga Programa, čiji su korisnici jedinice lokalne samouprave. 
dobra od interesa za Republiku Hrvatsku te imaju njezinu osobitu zaštitu. ${ }^{31}$ Oni su za državu bitni zbog obrambenog, gospodarskog, ekološkog i brojnih drugih razloga. ${ }^{32}$ Šume i šumska zemljišta štite se i koriste na način određen Zakonom o šumama i posebnim propisima. Državni interes nad šumama i šumskim zemljištem također se štiti značajnim ograničenjima. ${ }^{33}$ Za razliku od poljoprivrednoga zemljišta, šume i šumska zemljišta dani su na opću uporabu svim građanima, sve dok iz takve uporabe nisu izuzeti. Tako se fizičke osobe mogu kretati šumom ili šumskim zemljištem kao posjetitelji šuma, ako nije drugačije određeno Zakonom o šumama ili drugim propisom. ${ }^{34}$ Također, ako to nije u suprotnosti sa šumskogospodarskim planovima i posebnim propisima, Hrvatske šume d.o.o., trgovačko društvo osnovano za gospodarenje šumama i šumskim zemljištima u vlasništvu Republike Hrvatske, mogu u šumama u vlasništvu Republike Hrvatske predvidjeti za svoje potrebe i za potrebe građana, uz naknadu, sakupljanje šumskih proizvoda, iskorištavanje humusa i smolarenje, a pašarenje i žirenje u šumama i na šumskim zemljištima, osim u prebornim šumama, plantažama i regularnim šumama za trajanja obnove i rasta mladika i kultura u prvomu dobnom razredu, uz obvezatno čuvanje stoke. ${ }^{35} \mathrm{Da}$ se šume i šumska zemljišta trebaju smatrati financijskom imovinom, jasno proizlazi i iz namjene prihoda koji se ostvaruju od njihova iskorištavanja. ${ }^{36}$

31 Članak 2. te članak 4. stavci 1., 2. i 4. Zakona o šumama.

32 Vidi Belaj, Vlado, „Posebno stvarnopravno uređenje za šume i šumska zemljišta“, Stvarno pravo - posebna pravna uređenja, Narodne novine, Zagreb, 2011., str. 160.

33 Tako je, sukladno članku 52. Zakona o šumama, zabranjeno otuđivanje ovih površina iz vlasništva Republike Hrvatske, osim u slučajevima koji su propisani Zakonom o šumama. Također, strane pravne i fizičke osobe ne mogu stjecati pravo vlasništva na šumama i šumskome zemljištu, osim ako je međunarodnim ugovorom drukčije određeno.

34 Članak 12. stavak 1. Zakona o šumama.

35 Članak 33. stavak 1. Zakona o šumama. Kako šume imaju različitu namjenu, člankom 17. stavci. 1. do 3. Zakona o šumama, korištenje šuma također je povjereno različitim osobama. Šume po namjeni mogu biti gospodarske, zaštitne i šume s posebnom namjenom. Gospodarske šume uz očuvanje i unapređenje općekorisnih funkcija koriste se za proizvodnju šumskih proizvoda, zaštitne šume u prvom redu služe za zaštitu zemljišta, voda, naselja, objekata i druge imovine, dok šume s posebnom namjenom predstavljaju zaštićene dijelove prirode kao što su strogi rezervati, nacionalni parkovi, posebni rezervati, spomenici prirode, značajni krajobrazi, park-šume, zatim predstavljaju šume i dijelove šuma registrirane za proizvodnju šumskog sjemena, šume namijenjene znanstvenim istraživanjima te šume za potrebe obrane Republike Hrvatske. Ovisno o njihovoj namjeni, pojedine šume i šumska zemljišta u vlasništvu države koriste tijela državne uprave i pravne osobe čiji je osnivač Republika Hrvatska. Tako, primjerice, pojedinim šumama i šumskim zemljištima u vlasništvu Republike Hrvatske namijenjenima znanstvenim istraživanjima i nastavi mogu gospodariti samo pravne osobe sa statusom javne ustanove čiji je osnivač Republika Hrvatska i njihove znanstveno-nastavne sastavnice, koje svoju znanstveno-nastavnu djelatnost i znanstvenoistraživački rad obavljaju iz područja šumarstva.

36 Sukladno članku 46. stavak 2., članku 55. stavci 1. i 3., članku 61. stavci 1. i 2. te članku 62. i 63. Zakona o šumama, naknade ostvarene od korištenja šuma i šumskoga zemljišta plaćaju se u korist Hrvatskih šuma te se koriste u svrhu kupnje druge šume ili šumskog zemljišta u ime i za račun Republike Hrvatske ili za podizanje novih šuma, u svrhu gospodarenja šumama i šumskim zemljištima, odnosno za osiguravanje biološke obnove šuma te za znanstvene radove i programe u području šumarstva te za radove biološke obnove šuma, radove gospodarenja šumama na kršu, radove na sanaciji i obnovi sastojina ugroženih sušenjem i drugim nepogodama, za izgradnju šumskih prometnica, razminiranje šumskih površina te za ostale radove koji su prijeko potrebni za očuvanje i unapređenje općekorisne funkcije šume, radove sjemenarske i rasadničarske djelatnosti u šumarstvu, očuvanje genofonda i podizanje klonskih sjemenskih plantaža, te za znanstvene radove iz područja šumarstva. 
Konačno, vodno dobro čine zemljišne čestice koje obuhvaćaju vodonosna i napuštena korita površinskih voda, uređeno inundacijsko područje, neuređeno inundacijsko područje, prostor na kojem je izvorište voda namijenjeno ljudskoj potrošnji, potreban za njegovu fizičku zaštitu i prostor na kojem je izvorište, izdašnosti najmanje $10 \mathrm{~m}^{3}$ dnevno, prirodne mineralne, termalne i prirodne izvorske vode, potreban za njegovu fizičku zaštitu i otoke koji su nastali ili nastanu u vodonosnom koritu presušivanjem vode, njezinom diobom na više rukavaca, naplavljivanjem zemljišta ili ljudskim djelovanjem. Ovo dobro služi održavanju i poboljšanju vodnog režima, a osobito je namijenjeno građenju i održavanju regulacijskih i zaštitnih vodnih građevina i građevina za osnovnu melioracijsku odvodnju, održavanje korita i obala vodotoka, te održavanje i uređenje inundacijskog područja, građenje i održavanje građevina za unutarnju plovidbu, provedbu obrane od poplava te korištenje i zaštitu izvorišta voda namijenjenih ljudskoj potrošnji. ${ }^{37}$ Zakonom o vodama propisano je kako vodno dobro predstavlja dobro od interesa za Republiku Hrvatsku, da ima njezinu osobitu zaštitu te da se koristi na način i pod uvjetima propisanima tim Zakonom. ${ }^{38}$ Jedan dio vodnoga dobra, tj. zemljišne čestice vodnoga dobra koje su u vlasništvu Republike Hrvatske, naziva se javnim vodnim dobrom. ${ }^{39}$ Javni interes na javnom vodnom dobru štiti se vlasničkopravnim ograničavanjima stjecanja ovoga dobra. ${ }^{40}$ Javno vodno dobro može biti javno dobro u općoj uporabi i javno dobro u javnoj uporabi. Javno dobro u općoj uporabi dano je na jednaku i ravnopravnu

37 Članak 7., članak 8. stavak 1. i članak 9. Zakona o vodama. Vode su opće dobro i imaju osobitu zaštitu Republike Hrvatske. Slijedom toga, vode u tijelima površinskih i podzemnih voda ne mogu biti objektom prava vlasništva i drugih stvarnih prava. Jug naglašava kako je za razliku od voda, vodno dobro $\mathrm{u}$ vlasničkopravnom režimu te se na njemu, uz propisana ograničenja, mogu stjecati pravo vlasništva $\mathrm{i}$ druga stvarna prava. Jug, Jadranko, „Posebno stvarnopravno uređenje za vode i vodno dobro“, Stvarno pravo - posebna stvarna uređenja, Narodne novine, Zagreb, 2011., str. 278.

38 Članak 8. stavci 6. i 7. Zakona o vodama.

39 Unatoč preciznoj definiciji javnoga vodnoga dobra, definiranje ovih čestica u hrvatskom zakonodavstvu učinjeno je vrlo loše. Tako je člankom 11. stavcima 1. do 3. Zakona o vodama utvrđeno kako javno vodno dobro čine zemljišne čestice vodnoga dobra koje su do dana stupanja na snagu Zakona o vodama iz 1995. godine bile temeljem zakona ili temeljem bilo koje druge pravne osnove: opće dobro, javno dobro, javno vodno dobro, vodno dobro, javno dobro - vode, državno vlasništvo, vlasništvo jedinice lokalne samouprave, društveno vlasništvo bez obzira na to tko je bio nositelj prava korištenja, upravljanja ili raspolaganja, odnosno koje su u zemljišnoj knjizi bile upisane kao: javno dobro, javno vodno dobro, vodno dobro, državno vlasništvo, vlasništvo jedinice lokalne samouprave, društveno vlasništvo s naznakom ili bez naznake nositelja prava korištenja, upravljanja ili raspolaganja, općenarodna imovina, opće dobro i sl. Javnim vodnim dobrom smatraju se, sve dok se ne dokaže suprotno, i one zemljišne čestice vodnoga dobra koje do dana stupanja na snagu Zakona o vodama iz 2009. godine nisu bile upisane u zemljišnoj knjizi, odnosno koje su bile upisane u zemljišnu knjigu, ali nitko nije naznačen kao njihov vlasnik, kao i one koje se izvlaste ili otkupe u korist Republike Hrvatske. Josipović ističe kako iz Zakona o vodama proizlazi intencija zakonodavca da vodno dobro, kao dobro od interesa za Republiku Hrvatsku, u što je moguće većoj mjeri postane javno vodno dobro. Ona smatra kako bi se time osigurala bolja zaštita vodnoga dobra te bi se lakše osiguralo održavanje jedinstvenog vodnoga režima. Stoga je i Zakonom o vodama izričito propisano kako Republika Hrvatska ima pravo prvokupa kada vlasnik namjerava prodati česticu koja predstavlja vodno dobro. Josipović, „Posebni“, op. cit., str. 25.

40 Članak 11. članci 4. do 6. Zakona o vodama utvrđuje neotuđivost ovoga dobra te ga isključuje od stjecanja prava vlasništva i drugih stvarnih prava dosjelošću i na bilo koji drugi način stvarnoga prava, osim stjecanja prava služnosti i prava građenja temeljem toga Zakona. Slijedom toga, sukladno članku 14. stavak 1. Zakona o vodama, sve vodne građevine izgrađene na javnom vodnom dobru pripadnost su ovoga dobra sukladno načelu jedinstva nekretnine, osim vodnih građevina izgrađenih na temelju prava građenja dok to pravo traje, odnosno vodnih građevina izgrađenih na temelju prava služnosti vodova. 
upotrebu svim osobama. Tako svatko, pod jednakim uvjetima, može koristiti javno vodno dobro za odmor i rekreaciju, na način i u opsegu koje određuje tijelo jedinice lokalne ili područne (regionalne) samouprave, uz prethodnu suglasnost Hrvatskih voda. Za razliku od ovoga, javno dobro u javnoj upotrebi mogu koristiti isključivo ovlaštenici prava na njemu. Hoće li neki dio vodnoga dobra biti u općoj ili javnoj upotrebi odlučuje njegov vlasnik, tj. Republika Hrvatska. ${ }^{41}$ Da javno vodno dobro u javnoj uporabi treba smatrati financijskom imovinom države, jasno proizlazi iz namjene prihoda ostvarenoga od davanja ovoga dobra na korištenje privatnim osobama. Tako je prihod od naknade za pravo građenja i pravo služnosti na javnom vodnom dobru prihod državnoga proračuna, a prihod od naknade za pravo zakupa i najma na javnom vodnom dobru prihod Hrvatskih voda - pravne osobe sui generis koju je Republika Hrvatska osnovala u svrhu upravljanja vodama. ${ }^{42}$

Iz svega se može zaključiti kako poljoprivredno zemljište u vlasništvu države, šume i šumsko zemljište u vlasništvu države i javno vodno dobro u javnoj uporabi $\mathrm{u}$ potpunosti ispunjavaju pretpostavke za svrstavanje ovih dobara u financijsku imovinu Republike Hrvatske. Sve ove nekretnine nalaze se u vlasništvu Republike Hrvatske, nisu namijenjene niti općoj uporabi niti za ostvarivanje funkcija i nadležnosti države, već se trebaju koristiti isključivo za ostvarivanje prihoda svojih vlasnika. O njihovom značenju za državu posebno govori okolnost da su sva ova dobra utvrđena dobrima od interesa za Republiku Hrvatsku te slijedom toga uživaju njezinu osobitu zaštitu.

\section{PRAVNI OKVIR KORIŠTENJA POLJOPRIVREDNOGA ZEMLJIŠTA U VLASNIŠTVU DRŽAVE, ŠUMA I ŠUMSKOGA ZEMLJIŠTA U VLASNIŠTVU DRŽAVE TE JAVNOG VODNOGA DOBRA U JAVNOJ UPORABI}

Iako se na poljoprivredno zemljište, šume i šumsko zemljište te na vodno dobro u pravilu primjenjuju pravne norme građanskoga prava, zbog zaštite zakonom utvrđenoga interesa Republike Hrvatske na ovim dobrima pravni režim nekih normi građanskoga prava isključen je normama upravnog prava. Time norme upravnog prava imaju prednost u primjeni pred normama građanskoga prava. Norme upravnoga prava u prvome redu odnose se na upravljanje ovim dobrima. Kada je vlasnik tih dobara Republika Hrvatska, ona je pri upravljanju njima još obvezana postupati i sukladno posebnim pravilima koja jamče da će dobra biti iskorištena na način koji je najpovoljniji za državu. Slijedom navedenoga, norme upravnoga prava značajno sužavaju mogućnost kretanja ovih stvari u pravnom prometu, kao i mogućnosti njihove uporabe, s obzirom na to da se one, upravo zbog svojih posebnih svojstava, trebaju koristiti za zadovoljavanje nekih društvenih i gospodarskih potreba. Upravna ograničenja slobodnoga raspolaganja ovim dobrima

41 Članak 14. stavak 2. i članak 17. stavak 1. Zakona o vodama.

42 Članak 16. stavak 6. Zakona o vodama. 
česta su i u usporednome pravu. Tako je, primjerice, davanje nekoga dobra koje se smatra financijskom imovinom na korištenje privatnoj osobi u Austriji uvjetovano prethodnim odobrenjem nadzornoga tijela. Također, osoba javnog prava koja upravlja financijskom imovinom dužna je planirati prihode $\mathrm{i}$ rashode vezane uz korištenje ove imovine, a nad njezinom djelatnošću provodi se i sveobuhvatan proračunski i računovodstveni nadzor, u koju su svrhu ove osobe nadzornim tijelima obvezne redovito podnositi detaljne financijske izvještaje. ${ }^{43}$ Prilikom upravljanja financijskom imovinom, osoba javnoga prava u Francuskoj obvezna je skrbiti pažnjom dobroga domaćina, potencirati održivi razvoj ovih dobara te unapređivati njihove financijske doprinose. Raspolaganja ovim dobrima dopuštena su samo kada je to zakonom ili podzakonskim općim aktom izričito propisano te uz poštovanje strogih procedura usmjerenih zaštiti javnoga interesa. O načinu njihova korištenja odlučuje se javnopravnim instrumentom - upravnim aktom, na koji u pravilu suglasnost treba dati državno tijelo nadležno za poslove financija. Iznimno, ova dobra mogu se dati na korištenje i upravnim ugovorom ili ugovorom građanskoga prava. Najčešći oblici raspolaganja financijskom imovinom u Francuskoj su koncesija i zakup, a raspolaganje temeljem ugovora građanskoga prava dopušteno je jedino pod uvjetom da se radi o naplatnom pravnom poslu i da protučinidba nije niža od tržišne vrijednosti dobra koje ima status privatne domene. Konačno, sporovi vezani uz namjenu ovih dobara rješavaju se pred upravnim sudovima. ${ }^{44}$ Slično je i u Italiji gdje se šumama, pravom na istraživanje i eksploataciju rudnih bogatstava te pravom lova također može raspolagati jedino temeljem koncesije. ${ }^{45}$

U Hrvatskoj se posebna stvarnopravna uređenja uspostavljaju za one vrste stvari koje su radi svojih svojstava, funkcije ili namjene Ustavom ili zakonom utvrđene dobrima od interesa za Republiku Hrvatsku. ${ }^{46}$ Iako već Zakon o vlasništvu $i$ drugim stvarnim pravima određuje kako je svatko tko odlučuje o općim dobrima ili o stvarima u vlasništvu Republike Hrvatske ili njima upravlja dužan postupati kao dobar domaćin te da za to odgovara, ${ }^{47}$ svakom od ovih dobara zakonodavac

43 Antoniolli, Koja, op. cit., str. 697.

44 Vidi Gillet-Lorenzi, Traoré, S., op. cit., str. 132-133. te Auby, Bon, op. cit., str. 134.

45 Caringella, op. cit., str. 910.

46 Dobrima od interesa za Republiku Hrvatsku Ustav Republike Hrvatske, Narodne novine, br. 56/90, 135/97, 113/00, 28/01, 76/10 i 5/14, odredio je more, morsku obalu i otoke, vode, zračni prostor, rudno blago i druga prirodna bogatstva, te zemljište, šume, biljni i životinjski svijet, druge dijelove prirode, nekretnine i stvari od osobito kulturnog, povijesnog, gospodarskog i ekološkog značenja, koji su kao takvi određeni zakonom. U pravnoj teoriji ističe se kako interes Republike Hrvatske predstavlja izričaj kojim se poslužio zakonodavac da bi nazvao pravom zaštićeni opći interes društvene zajednice kao cjeline, na postizanju dobrobiti države i njezinih građana. Međutim, u teoriji se ujedno ističe kako je sadržaj pojma „dobra od interesa za Republike Hrvatsku“ nejasan, slijedom čega bi ovome pravnome standardu značenje trebala dati nadležna tijela koja se u praksi susreću s tim pojmom. Vidi Gavella, op. cit., str. 9-12. te Gavella, Nikola, „Građansko pravo i posebna pravna uređenja za određene vrste dobara“, Zbornik Pravnoga fakulteta u Zagrebu, vol. 62, br. 5-6, 2012., str. 1461-1463. Isto ističu i Babac, Branko, Upravno pravo, Pravni fakultet u Osijeku, Osijek, 2004., str. 660. te Ljubanović, Boris, „Vrednovanje javnih dobara - koncesije na 'kulturnim dobrima' kao 'dobrima od interesa za Republiku Hrvatsku', s posebnim naglaskom na posebnosti tih koncesija“, Zbornik radova Pravnog fakulteta u Splitu, god. 46. br. 1, 2009., str. 194.

47 Članak 35. stavak 7. Zakona o vlasništvu i drugim stvarnim pravima. 
je utvrdio neke specifičnosti u pravnome režimu i propisao ih zakonom kojim se uređuju ova dobra. Tako upravljanje i korištenje poljoprivrednim zemljištem uređuje Zakon o poljoprivrednom zemlijištu, upravljanje i korištenje šumama i šumskim zemljištem uređuje Zakon o šumama, a upravljanje i korištenje javnim vodnim dobrom uređuje Zakon o vodama. Ovi zakoni predstavljaju lex specialis za postupanje u svezi s navedenim zemljištima te se u svezi s pojedinim materijalnim i postupovnim pitanjima ponajprije treba primijeniti upravo ove zakone, a opće propise o raspolaganju nekretninama tek supsidijarno i to samo ako ovim zakonima nije drugačije određeno. ${ }^{48}$

I Zakon o poljoprivrednom zemljištu i Zakon o šumama i Zakon o vodama propisuju oblike korištenja ovih zemljišta kada se ona nalaze u vlasništvu države. Međutim, neki od njih ustupanje ovih dobara na korištenje uređuju detaljnije, a neki samo općenito, čime je pravni doseg njihove regulacije daleko od ujednačenoga. Bilo bi korisno kada bi se pri reguliranju korištenja ovih dobara, bez obzira na zakon kojim je ono uređeno, osiguralo jednostavno i pravovremeno odlučivanje o davanju ovih zemljišta na korištenje, kako bi se ona u najvećoj mogućoj mjeri stavila u gospodarsku funkciju te se time potakla gospodarska aktivnost i zapošljavanje. Ovi zakoni trebali bi ujedno utjeloviti i primjenu načela tržišnoga natjecanja, zaštite vrijednosti i namjene ovih dobara, a sve kako bi se osigurala optimalna iskoristivost i zaštitila njihova namjena. $\mathrm{S}$ tim ciljem, pravna regulacija davanja na korištenje ovih dobara treba sadržavati postupovna pravila koja će dovesti do davanja zemljišta na korištenje poduzetniku koji će uz podizanje ili barem očuvanje vrijednosti ovih zemljišta državi zajamčiti ostvarivanje maksimalnih prihoda.

Zakon o poljoprivrednom zemljištu, Zakon o šumama i Zakon o vodama propisuju mogućnost davanja ovih zemljišta na korištenje privatnim osobama putem instituta zakupa, služnosti i prava građenja. Pri tome, Zakon o vodama propisuje još mogućnost davanja javnog vodnog dobra u javnoj uporabi u najam. No, postupci dodjele ovih zemljišta na korištenje koji se propisuju spomenutim zakonima ili se propisuju na temelju ovih zakona uređeni su vrlo raznoliko. Slijedom toga, kao rezultat različitoga normiranja postupaka koji imaju istovjetan cilj, kao rezultat propisivanja određenih dijelova ovih postupaka podzakonskim propisima, kao rezultat propuštanja definiranja pravne prirode odluka kojima se odlučuje o najpovoljnijem ponuditelju i pravne prirode ugovora koji se sklapa s ovom osobom te poradi drugih dvojbi koje iz ovih zakona proizlaze - u hrvatskom pravnom sustavu javlja se značajna pravna nesigurnost. Nomotehničkoj kvaliteti zakona koji uređuju korištenje nekih oblika financijske imovine prigovara se i u stručnoj literaturi, pa se tako primjerice navodi kako je razina normiranosti raspolaganja nekretninama u javnom vlasništvu u nekim zakonima u Hrvatskoj nezadovoljavajuća i nedovoljno precizna, kako se u zakonima koriste pravni standardi koji omogućuju različito tumačenje što u praksi zatim izaziva teškoće u primjeni, ali i omogućuje zloporabe, kako samo površan pogled na ove zakone pokazuje mnoge nepotrebne razlike u

48 U svezi s upravljanjem i korištenjem poljoprivrednoga zemljišta ovo izričito propisuje članak 25. stavak 1. Zakona o poljoprivrednom zemljištu. 
svezi s raspolaganjem nekretninama i tendenciju uređenja pravnih odnosa s pozicije javne vlasti, uz odgovarajuću primjenu općih pravila stvarnog i obveznog prava, što sve zatim izaziva nedoumice glede primjene ovih propisa i sl. ${ }^{49}$ Stoga treba razmotriti na koji su način ovi postupci u Hrvatskoj uređeni te konkretno ukazati na neke njihove suštinske nedostatke, a sve s ciljem izmjene postojećih zakona i prilagođavanja ovih instituta njihovoj iskonskoj svrsi i namjeni.

\subsection{Pravni okvir davanja na korištenje poljoprivrednog zemljišta u vlasništvu države}

Davanju poljoprivrednoga zemljišta u vlasništvu države na korištenje privatnim osobama posvećen je velik dio Zakona o poljoprivrednom zemljištu. Čak 26 od ukupno 85 članaka ovoga Zakona uređuje davanje zemljišta na korištenje privatnim osobama. Ovaj Zakon najprije pobraja oblike korištenja poljoprivrednoga zemljišta u vlasništvu države razlikujući zakup i zakup za ribnjake, zakup zajedničkih pašnjaka, privremeno raspolaganje, osnivanje prava građenja, osnivanje prava služnosti $i$ davanje poljoprivrednoga zemljišta na korištenje bez javnoga poziva, a zatim uređuje svaki od ovih postupaka. ${ }^{50}$ No, unatoč opsežnoj zakonskoj regulaciji, brojna važna materijalna i postupovna pitanja Zakon o poljoprivrednom zemljištu prepustio je podzakonskom normiranju. Takvo reguliranje dovelo je do značajne nesistematičnosti i neosnovane neujednačenosti analognih instituta korištenja nekoga vida poljoprivrednoga zemljišta, pa se oni danas značajno razlikuju po pitanju roka, sadržaja ponude, uvjetima davanja u zakup, kriterijima odabira ponude, ovlastima za predlaganje odluke o davanju na korištenje poljoprivrednoga zemljišta i sl., čime su preglednost i razumljivost ovih propisa, a time i njihova primjena, značajno otežane. Poseban problem ogleda se u okolnosti da na neka važna postupovna pitanja Zakon o poljoprivrednom zemljištu ne daje precizan odgovor, niti jamči učinkovite mehanizme zaštite javnoga interesa nad ovim prostorom od posebnoga interesa za državu. Stoga se ovome Zakonu u cjelini može uputiti nekoliko značajnijih prigovora.

Prvi važan nedostatak ovoga Zakona odnosi se na nejednaku važnost koju posvećuje različitim institutima koji su u njemu sadržani. Zakon detaljno propisuje ovlaštenike, uvjete i postupak davanja poljoprivrednoga zemljišta u zakup i zakup za ribnjake, no, u svezi sa zakupom zajedničkih pašnjaka, davanjem poljoprivrednoga zemljišta na korištenje bez javnog poziva i privremenim raspolaganjem ovim

49 Jelčić, op. cit., str. 2. te str. 33-34.

50 Članak 25. stavak 2. Zakona o poljoprivrednom zemljištu. Sukladno člancima 43. do 49. prijašnjeg Zakona o poljoprivrednom zemljištu, poljoprivredno zemljište moglo se dati na korištenje još i putem koncesije. Ove odredbe potom su ukinute, no člancima 61. do 70. istoga Zakona ostavljena je mogućnost dodjele koncesije na ribnjacima. Najznačajnija razlika između davanja poljoprivrednoga zemljišta $u$ zakup i u koncesiju sukladno ranijim propisima bila je duljina razdoblja na koju se zemljište davalo na korištenje privatnim osobama. Vidi Josipović, „Posebni“, cit., str. 15. O ranijem uređenju koncesija na poljoprivrednome zemljištu više vidi u: Lukačević-Subotić, Željka, „Uređenje instituta koncesije na pojedinim javnim dobrima u zakonodavstvu Republike Hrvatske s posebnim osvrtom na poljoprivredno zemljište u vlasništvu države“, Hrvatska pravna revija, god. 3., br. 3, 2003., str. 16-20. 
zemljištem, pozivajući se na supsidijarnu primjenu odredbi za davanje ovih zemljišta u zakup utvrđuje samo pojedine specifičnosti kao što su rok za davanje u zakup, sadržaj ponude, nadležnost tijela koja sudjeluju u donošenju odluke, uvjete raskida ugovora i sl. Pridavanje različitoga značaja pojedinim institutima u istome Zakonu nije neuobičajeno, posebno s obzirom na to da se neki od njih primjenjuju češće, a drugi rjeđe, te neki pojedincima daju prava na dugi niz godina. Međutim, vezano uz postupak osnivanja prava građenja i osnivanja prava služnosti na poljoprivrednom zemljištu u vlasništvu države Zakon jedino određuje nadležnost Agencije za poljoprivredno zemljište za osnivanje ovih prava, ne propisujući ni uvjete ni postupak njihova osnivanja. Uređenje ovih postupovnih pitanja zakonodavac je jednostavno prepustio Vladi, koja ih treba normirati uredbom. Iako je ove uredbe Vlada Republike Hrvatske trebala donijeti najkasnije do 30. srpnja 2015. godine, one nisu donesene do danas, čime je pravni okvir osnivanja prava građenja i prava služnosti na poljoprivrednom zemljištu nepotpun, a time i neprilagođen za jednostavnu i transparentnu primjenu. ${ }^{51}$

Regulaciji osnivanja prava građenja i prava služnosti na poljoprivrednom zemljištu u vlasništvu države može se uputiti još jedan značajan prigovor. Zakon o poljoprivrednom zemljištu propisuje kako se odlukom kojom se odlučuje o vlasničkim i drugim stvarnim pravima na poljoprivrednom zemljištu u vlasništvu države - a to odlučivanje podrazumijeva i osnivanje prava građenja i služnosti na poljoprivrednom zemljištu u vlasništvu države - obvezno treba osigurati zaštita i unapređenje gospodarskih, ekoloških i drugih interesa Republike Hrvatske i njezinih građana. Međutim, suprotno naglasku koji je stavljen na zaštitu i unapređenje naznačenih interesa države na ovome zemljištu, isti članak propisuje kako odluka o ovim stvarnim pravima nije upravni akt, slabeći na taj način javnopravnu komponentu ovlasti države da autoritarnim mjerama štiti ovo izuzetno važno državno dobro. ${ }^{52}$ Nije jasno zašto je zakonodavac Zakonom izričito oslabio pravni učinak takve odluke, unatoč tome što je poljoprivredno zemljište utvrdio dobrom od interesa za

51 Vidi članak 40. stavak 1. Zakona o izmjenama i dopunama Zakona o poljoprivrednom zemljištu, Narodne novine, br. 48/15. Na ove postupke ne primjenjuje se Uredba o osnivanju prava građenja i prava služnosti na nekretninama u vlasništvu Republike Hrvatske, Narodne novine, br. 10/14 i 95/15, donesena temeljem Zakona o upravljanju državnom imovinom, Narodne novine, br. 94/13 i 18/16, s obzirom na to da se temeljem članka 1. ove Uredbe njome uređuju način i uvjeti osnivanja prava građenja i prava služnosti na nekretninama u vlasništvu Republike Hrvatske kojima upravlja Državni ured za upravljanje državnom imovinom te način i uvjeti za osnivanje prava građenja i prava služnosti na nekretninama u vlasništvu Republike Hrvatske u svrhu izgradnje postrojenja obnovljivih izvora energije i kogeneracije, kao što su vjetroelektrane, sunčane elektrane, postrojenja na bioplin, postrojenja na biomasu i dr., te infrastrukturnih objekata vezanih uz rad postrojenja, kao i u svrhu realizacije turističkih projekata. Kako poljoprivrednim zemljištem upravlja Agencija za poljoprivredno zemljište, a ne Državni ured za upravljanje državnom imovinom, ova uredba ne odnosi se na osnivanje prava građenja i prava služnosti na poljoprivrednom zemljištu u vlasništvu države.

52 Članak 26. Zakona o poljoprivrednom zemljištu. Zanimljivo je spomenuti kako je ovo pitanje bilo drukčije uređeno Zakonom o poljoprivrednom zemljištu, Narodne novine, br. 66/01, 87/02, 48/05, 90/05 i 152/08. Ovaj Zakon člankom 14. utvrdio je kako se na poljoprivrednom zemljištu koje je obuhvaćeno hidromelioracijskim sustavom, može osnovati služnost u svrhu dovođenja i odvođenja voda, propisujući kako se protiv odluke o osnivanju služnosti koju je donosila županijska skupština odnosno skupština Grada Zagreba, može pokrenuti upravni spor, iz čega se može zaključiti kako je odluka o osnivanju služnosti po pravnoj prirodi bila upravni akt. 
Dr. sc. Dario Đerđa: Pravni okvir korištenja nekih oblika financijske imovine u Republici Hrvatskoj Zbornik radova Pravnog fakulteta u Splitu, god. 54, 1/2017., str. 121.-158.

Republiku Hrvatsku te mu zajamčio osobitu zaštitu. Pridavanje ovoj odluci značaja upravnoga akta omogućilo bi potencijalnim ponuditeljima adekvatna sredstva pravne zaštite koja bi oni mogli koristiti protiv ove odluke, a državi učinkovitu zaštitu ovih dobara.

Treći prigovor ovome Zakonu može se uputiti zbog prilično nejasnoga načina regulacije davanja poljoprivrednoga zemljišta u zakup. Kao što je već navedeno, Zakonom o poljoprivrednom zemljištu najdetaljnije je uređeno davanje poljoprivrednoga zemljišta u vlasništvu države u zakup. Iako zakonodavac razlikuje davanje u zakup poljoprivrednog zemljišta, zakup ribnjaka, zakup neizgrađenoga građevinskoga zemljišta koje je po uporabnom svojstvu poljoprivredno zemljište i zakup zajedničkih pašnjaka, sva su ova zemljišta poljoprivredno zemljište te ne trebaju imati zasebne režime. Razlikovanje zakupa poljoprivrednoga zemljišta u vlasništvu države prema objektu rezultira jedino nekim ograničenjima koja se odnose na specifičnu vrstu poljoprivrednoga zemljišta. ${ }^{53}$ No, u većini drugih pitanja davanje u zakup bilo koje od ovih vrsta poljoprivrednoga zemljišta odvija se sukladno jednakim pravilima utvrđenima za davanje poljoprivrednoga zemljišta u vlasništvu države u zakup. ${ }^{54}$ Ovdje bi bilo jednostavnije istaknuti razlike koje se javljaju u ovlaštenicima pojedine specifične vrste dobara na kojima se zakup

53 Tako se, sukladno člancima 14. i 15. Zakona o poljoprivrednom zemljištu, u zakup za poljoprivredne namjene može dati neizgrađeno građevinsko zemljište u vlasništvu države koje je po uporabnom svojstvu poljoprivredno zemljište. No, kako je ovo zemljište primarno namijenjeno gradnji, ono se ne može koristiti za podizanje trajnih nasada ili izgradnju objekata u svrhu poljoprivredne proizvodnje. Specifičnost davanja u zakup za poljoprivredne namjene neizgrađenoga građevinskoga zemljišta čini vremensko ograničenje davanja ovoga zemljišta u zakup najviše na deset godina, odnosno do nastupa nekog od razloga za prestanak takvoga zakupa sadržanoga u ugovoru o zakupu.

54 Tako je, primjerice, člankom 15. stavak 3. Zakona o poljoprivrednom zemljištu propisano kako se na davanje u zakup neizgrađenoga građevinskoga zemljišta koje je po uporabnom svojstvu poljoprivredno zemljište odgovarajuće primjenjuju odredbe o davanju poljoprivrednog zemljišta u vlasništvu države $u$ zakup, dok je člankom 47. stavak 5. istoga Zakona propisano kako se na ugovor o zakupu zajedničkoga pašnjaka odgovarajuće primjenjuju odredbe o ugovoru o zakupu poljoprivrednoga zemljišta. Iznimku od ovih pravila predstavlja davanje poljoprivrednoga zemljišta u vlasništvu države nekom pojedincu na privremeno korištenje te davanje poljoprivrednoga zemljišta u vlasništvu države bez poziva, koji su uređeni člancima 48., 51. i 52. Zakona o poljoprivrednom zemljištu. U prvom slučaju radi se o poljoprivrednom zemljištu u vlasništvu države koje je pogodno za poljoprivrednu proizvodnju, a za koje nisu sklopljeni ugovori o zakupu. Agencija može sklopiti ugovor o privremenom korištenju ovoga zemljišta s fizičkim ili pravnim osobama koje u tu svrhu podnesu zahtjev. Međutim, krug ovih osoba usko je ograničen Zakonom. To su dosadašnji posjednici kojima su istekli ugovori o zakupu poljoprivrednog zemljišta u vlasništvu države i koji su u mirnom posjedu istoga; ili koji su koristili poljoprivredno zemljište u vlasništvu države bez ugovora i u mirnom su posjedu istoga; ili koji su koristili zajedničke pašnjake u vlasništvu države bez ugovora i u mirnom su posjedu istoga. Takav ugovor sklapa se na rok do pet godina, odnosno do sklapanja ugovora o zakupu poljoprivrednog zemljišta ili ugovora o zakupu zajedničkih pašnjaka, odnosno drugog oblika raspolaganja poljoprivrednim zemljištem sukladno odredbama toga Zakona. U drugom slučaju radi se o davanju poljoprivrednoga zemljišta u vlasništvu države znanstveno-nastavnim institucijama iz područja poljoprivrede te kaznionicama i ustanovama koje u obavljanju svoje djelatnosti imaju potrebu za poljoprivrednim zemljištem, a čiji je osnivač Republika Hrvatska ili neka jedinica područne (regionalne) samouprave. I u ovome slučaju poljoprivredno zemljište na korištenje ustupa Agencija uz suglasnost Ministarstva poljoprivrede, a u svrhu stručnoga i znanstveno-nastavnog rada, rehabilitacije i socijalizacije ili druge potrebe poljoprivredne namjene, na rok do 25 godina. Poljoprivredno zemljište također se dodjeljuje na zahtjev zainteresirane osobe, sastavni dio kojega je Gospodarski program. Na osnovi ove odluke ravnatelj Agencije u ime Republike Hrvatske i podnositelj zahtjeva sklapaju ugovor o davanju na korištenje poljoprivrednog zemljišta u vlasništvu države u pisanom obliku. 
daje i uvjetima davanja, negoli što bi to trebao biti slučaj sa zasebnim izdvajanjem regulacije svakoga od postupaka kojim se na korištenje daje posebna vrsta poljoprivrednoga zemljišta. Iako je postupak davanja u zakup poljoprivrednoga zemljišta dobro osmišljen i strukturiran, ovaj je postupak poradi nomotehničkih manjkavosti učinjen složenim za javnopravna tijela koja ga trebaju provesti, a još složenijim za osobe zainteresirane uzeti ove površine u zakup.

Pojednostavljeno, postupak davanja u zakup poljoprivrednoga zemljišta u vlasništvu države, postupak davanja u zakup ribnjaka i zajedničkih pašnjaka, kao i postupak davanja ovoga zemljišta na privremeno korištenje odvija se na sljedeći način. Svaki od njih započinje objavom javnoga poziva. Krug ovlaštenika iniciranja ovoga postupka zakonodavac je postavio vrlo široko, čime je pokazao svijest o važnosti iskorištavanja poljoprivrednoga zemljišta putem zakupa. Tako postupak davanja u zakup poljoprivrednoga zemljišta u vlasništvu države može pokrenuti Agencija za poljoprivredno zemljište po službenoj dužnosti te na inicijativu jedinice lokalne samouprave. Kako bi jedinica lokalne samouprave trebala voditi računa o iskoristivosti poljoprivrednih površina na svome području, kada ocijeni da se ono treba dati u zakup, zahtjevom se obraća Agenciji, tražeći raspisivanje javnoga poziva za davanje poljoprivrednoga zemljišta ili ribnjaka u zakup. U tom slučaju jedinica lokalne samouprave ujedno treba pripremiti svu dokumentaciju potrebnu za raspisivanje ovoga poziva i dostaviti je Agenciji. ${ }^{55}$ U Zakonu se posebno pohvalnim može ocijeniti što je zakonodavac zainteresiranome pojedincu podijelio pravo da jedinici lokalne samouprave sugerira kako bi se neko poljoprivredno zemljište moglo dati u zakup, a koje je on zainteresiran iskorištavati, čime je ovim osobama priznao pravni interes u postupku davanja ovoga zemljišta u zakup. U tom se slučaju pojedinac zahtjevom obraća jedinici lokalne samouprave. Ona ovaj zahtjev treba razmotriti te eventualno predložiti Agenciji raspisivanje javnoga poziva. Štiteći pravne interese pojedinca, Zakon ovdje ide i korak dalje, priznajući ovoj osobi pravo da kada jedinica lokalne samouprave u roku od 30 dana od podnošenja takvoga zahtjeva ne predloži Agenciji raspisivanje javnoga poziva, ona može sama prikupiti potrebnu dokumentaciju te je uz zahtjev za raspisivanje poziva dostaviti izravno Agenciji. Obveza pojedinca da sam prikuplja dokumentaciju

55 Sukladno člancima 2. i 3. Pravilnika o dokumentaciji potrebnoj za raspisivanje javnog poziva za zakup, zakup za ribnjake $i$ zamjenu poljoprivrednog zemljišta u vlasništvu Republike Hrvatske, Narodne novine, br. 84/13. i 45/14., dokumentaciju potrebnu za raspisivanje javnog poziva za zakup poljoprivrednog zemljišta predstavlja popunjeni obrazac zahtjeva s popisom katastarskih čestica za koje se traži raspisivanje javnog poziva te uvjerenje jedinice lokalne samouprave da poljoprivredno zemljište nije dano u neki od oblika raspolaganja državnim poljoprivrednim zemljištem. Dokumentacija potrebna za raspisivanje javnog poziva za zakup za ribnjake mnogo je složenija te obuhvaća popunjeni obrazac zahtjeva s popisom katastarskih čestica za koje se traži raspisivanje javnog poziva, zemljišnoknjižne izvatke u elektroničkom obliku, posjedovne listove u elektroničkom obliku, uvjerenje upravnog tijela županije, odnosno Grada Zagreba nadležnog za prostorno uređenje o tome nalazi li se prema prostornom planu uređenja poljoprivredno zemljište izvan granica građevinskog područja, posebne uvjete zaštite prirode koje utvrđuje središnje tijelo državne uprave nadležno za poslove zaštite prirode, ako se poljoprivredno zemljište nalazi unutar zaštićenog područja, posebne uvjete za korištenje voda koje izdaju Hrvatske vode sukladno posebnom propisu o vodama te očitovanje Hrvatskog centra za razminiranje nalazi li se katastarska čestica u minski sumnjivom području katastarskih općina u Republici Hrvatskoj u kojima je utvrđeno postojanje minski sumnjivih površina. 
Dr. sc. Dario Đerđa: Pravni okvir korištenja nekih oblika financijske imovine u Republici Hrvatskoj Zbornik radova Pravnog fakulteta u Splitu, god. 54, 1/2017., str. 121.-158.

za raspisivanje javnoga poziva čini se vrlo nepravičnom, jer je ovo obveza javne vlasti, a nikako zainteresirane osobe, što predstavlja još jedan vid loše normativne uređenosti postupaka davanja u zakup poljoprivrednoga zemljišta u vlasništvu države. U ovome bi slučaju bilo ispravnije obvezati Agenciju da pribavi potrebnu dokumentaciju, kako je već propisano u slučaju kada po službenoj dužnosti raspisuje javni poziv. ${ }^{56}$ Iznimku od pravila da zahtjev podnosi jedinica lokalne samouprave predstavlja zakup zajedničkih pašnjaka, gdje zahtjev za raspisivanje javnoga poziva zainteresirana osoba dostavlja izravno Agenciji. ${ }^{57}$

Međutim, unatoč široko postavljenoj inicijativi za davanje u zakup poljoprivrednoga zemljišta, odluku o raspisivanju javnog poziva uvijek donosi Agencija za poljoprivredno zemljište. Ako Agencija smatra da zahtjev jedinice lokalne samouprave ili pojedinca nije osnovan, neće pokrenuti postupak. No, Zakon o poljoprivrednom zemljištu u tom slučaju ne propisuje koja je obveza Agencije, što dovodi do pravne praznine u svezi sa zaštitom prava ovih podnositelja takvih zahtjeva. U tom bi slučaju supsidijarno trebalo primijeniti Zakon o općem upravnom postupk $u^{58}$ te bi Agencija trebala donijeti rješenje kojim takav zahtjev odbija. Protiv rješenja Agencije podnositelj zahtjeva trebao bi moći koristiti dopuštena pravna sredstva, tj. pokrenuti upravni spor. ${ }^{59} \mathrm{Na}$ taj način u potpunosti bi se zaštitilo pravo zainteresirane osobe inicirati davanje neiskorištenoga poljoprivrednoga zemljišta $u$ vlasništvu države u zakup.

Zainteresirani pojedinci na javni poziv dostavljaju ponude, čiji bitan sastavni dio predstavlja obrazac Gospodarskog programa korištenja poljoprivrednog zemljišta u vlasništvu države. ${ }^{60}$ Zakon o poljoprivrednom zemljištu propisuje posebne kriterije koje podnositelj ponude mora ispuniti, statusne i financijske pretpostavke te pretpostavke o ranijem korištenju poljoprivrednoga zemljišta. ${ }^{61}$

56 Članak 28. Zakona o poljoprivrednom zemljištu.

57 Člancima 2. i 3. Pravilnika o načinu i uvjetima za podnošenje zahtjeva za raspisivanje javnog poziva te kriterijima za dodjelu u zakup zajedničkih pašnjaka u vlasništvu Republike Hrvatske, Narodne novine, br. 68/15, propisane su statusne pretpostavke za podnošenje takvoga zahtjeva te obvezan sadržaj toga zahtjeva.

58 Sukladno članku 3. Zakona o općem upravnom postupku, Narodne novine, br. 47/09, ovaj se Zakon primjenjuje u svim upravnim stvarima.

59 Ovakav zaključak proizlazi iz naziva podneska koji su jedinica lokalne samouprave odnosno zainteresirani pojedinac ovlašteni podnijeti Agenciji za poljoprivredno zemljište. Sukladno članku 41. Zakona o općem upravnom postupku, ovaj postupak pokreće se na zahtjev stranke, tj. osobe koja u predmetu ima pravni interes. Pravni interes podnositelja takvoga zahtjeva proizlazi iz članka 28. stavak 2. Zakona o poljoprivrednome zemljištu. O ovome zahtjevu, sukladno članku 96. stavak 1. Zakona o općem upravnom postupku, Agencija je obvezna odlučiti rješenjem, a protiv njega podnositelj zahtjeva ima pravo izjaviti sredstva pravne zaštite.

60 Sukladno članku 29. stavci 6. i 7. Zakona o poljoprivrednom zemljištu, obrazac Gospodarskog programa korištenja poljoprivrednog zemljišta u vlasništvu države sadržava podatke o podnositelju ponude, opis gospodarstva, pokazatelje poslovanja iz prethodnog razdoblja, namjenu korištenja i lokalitet zemljišta, tehnološko-tehničke karakteristike gospodarskog rada, podatak o potrebnoj mehanizaciji za obradu zemljišta koje je predmet zakupa, investicije i zapošljavanje, očekivane financijske rezultate proizvodnje, prikaz očekivanih troškova i prihoda te posebnu naznaku kada se radi o ekološkoj proizvodnji.

${ }_{61}$ Ovi kriteriji različiti su za davanje u zakup poljoprivrednog zemljišta i ribnjaka te davanje u zakup zajedničkih pašnjaka. Vidi članak 29. stavci 1. do 5. te članak 47. stavak 2. Zakona o poljoprivrednom zemljištu. 
Dr. sc. Dario Đerđa: Pravni okvir korištenja nekih oblika financijske imovine u Republici Hrvatskoj Zbornik radova Pravnog fakulteta u Splitu, god. 54, 1/2017., str. 121.-158.

Ujedno propisuje koji se parametri trebaju uzeti u obzir pri donošenju odluke kojoj će se osobi poljoprivredno zemljište dati u zakup te određuje uvjete prava prvenstva pri odabiru potencijalnoga zakupoprimca. ${ }^{62}$ Niz tehničkih pitanja Zakon je prepustio regulaciji podzakonskim propisima pa je tako propisao kako obrazac i način vrednovanja Gospodarskog programa u smislu određivanja vrijednosti i težine pojedine sastavnice uredbom propisuje Vlada Republike Hrvatske, kako se početna zakupnina utvrđuje sukladno pravilniku koji donosi ministar nadležan za poslove poljoprivrede, kako postupak javnog nadmetanja kada je više ponuditelja ostvarilo jednak maksimalni broj bodova propisuje ministar nadležan za poslove poljoprivrede te kako ovaj ministar pravilnikom propisuje zahtjeve i kriterije za dodjelu zajedničkih pašnjaka. ${ }^{63}$ Valja naglasiti da ovi podzakonski propisi uređuju neka postupovna i materijalna pitanja koja bi inicijalno trebala biti propisana Zakonom te da se njima propisuju i neki postupci koji se čine potpuno suvišnima i neopravdanima. ${ }^{64}$

Odluku o dodjeli poljoprivrednog zemljišta u vlasništvu države u zakup donosi Agencija za poljoprivredno zemljište. Ovu odluku Agencija donosi na prijedlog ili uz suglasnost različitih tijela ili potpuno samostalno, kako u kojem slučaju. ${ }^{65}$

62 Vidi članak 29. stavci 8. i 9. i članak 30. Zakona o poljoprivrednom zemljištu te članak 5. Pravilnika o načinu i uvjetima za podnošenje zahtjeva za raspisivanje javnog poziva te kriterijima za dodjelu u zakup zajedničkih pašnjaka u vlasništvu Republike Hrvatske.

63 Članak 29. stavak 10. te članak 31. stavci 1. i 3. te članak 47. stavak 10. Zakona o poljoprivrednom zemljištu.

64 Tako se, primjerice, dodatni postupak odabira kandidata, propisan člancima 2. do 7. Pravilnika o postupku javnog nadmetanja za utvrdivanje najpovoljnijeg ponuditelja na javnom pozivu za dodjelu poljoprivrednog zemljišta u vlasništvu Republike Hrvatske u zakup i zakup za ribnjake, Narodne novine, br. 120/13 i 98/15, može ocijeniti suvišnim s obzirom na to da je postupak ovdje već pokrenut raspisivanjem poziva za dodjelu zakupa te bi trebao biti okončan bez dodatnoga postupka. U ovome postupku po pozivu Agencije na dostavu ponude na javnom nadmetanju sudionicima koji su sudjelovali na javnom pozivu i ostvarili jednaki najviši zbroj bodova, ove osobe dostavljaju ponudu koja mora sadržavati propisane elemente, a među njima se posebno vrednuje iznos zakupnine koja se nudi na javnom nadmetanju. Odluku o odabiru najpovoljnijega ponuditelja donosi povjerenstvo za dodjelu zakupa na poljoprivrednom zemljištu u vlasništvu Republike Hrvatske i povjerenstvo za dodjelu zakupa na poljoprivrednom zemljištu u vlasništvu Republike Hrvatske za ribnjake, a najpovoljnijim ponuditeljem smatra se ponuditelj koji je na javnom nadmetanju ponudio najvišu zakupninu. Ako dva ponuditelja ponude jednaku zakupninu na javnom nadmetanju, najpovoljnijim ponuditeljem smatra se ponuditelj čija je ponuda na javnom nadmetanju ranije zaprimljena. Mnogo je bolje člankom 47. stavak 3. Zakona o poljoprivrednom zemljištu i člankom 6. stavak 2. Pravilnika o načinu i uvjetima za podnošenje zahtjeva za raspisivanje javnog poziva te kriterijima za dodjelu u zakup zajedničkih pašnjaka u vlasništvu Republike Hrvatske razrađen kriterij dodjele u zakup zajedničkih pašnjaka koji propisuje da se u slučaju jednakoga broja bodova najboljih ponuditelja prednost daje prebivalištu, odnosno sjedištu ponuditelja na području jedinice lokalne samouprave gdje se zajednički pašnjak nalazi ili prebivalištu, odnosno sjedištu ponuditelja na području susjedne jedinice lokalne samouprave, najmanje dvije godine do objave javnoga poziva.

65 Tako, primjerice, sukladno članku 27. stavci 7. i 8. Zakona o poljoprivrednom zemljištu, Agencija ovu odluku donosi na prijedlog Povjerenstava za dodjelu zakupa na poljoprivrednom zemljištu u vlasništvu Republike Hrvatske kada se radi o dodjeli zakupa na poljoprivrednom zemljištu, a na prijedlog Povjerenstva za dodjelu zakupa na poljoprivrednom zemljištu u vlasništvu Republike Hrvatske za ribnjake kada se radi o dodjeli zakupa na ribnjacima. Sukladno članku 15. stavci 1. i 2. Zakona o poljoprivrednom zemljištu, kada se radi o davanju u zakup neizgrađenog građevinskog zemljišta u vlasništvu države koje je po uporabnom svojstvu poljoprivredno zemljište, ovu odluku donosi uz suglasnost Državnog ureda za upravljanje državnom imovinom, dok, sukladno članku 47. stavak 4. istoga Zakona, odluku o dodjeli zakupa zajedničkoga pašnjaka donosi bez prijedloga nekog specijaliziranoga tijela. 
Nije jasan razlog sudjelovanja različitih tijela u postupku donošenja ove odluke te $s$ različitim ovlastima koje imaju, ovisno o vrsti poljoprivrednoga zemljišta koje se daje u zakup. Međutim, važniji nedostatak pravne regulacije odluke od davanju poljoprivrednoga zemljišta u zakup usmjeren je na propuštanje definiranja pravne prirode ove odluke, što u praksi izaziva brojne dvojbe. Čini se kako bi ona trebala biti upravni akt, što bi podrazumijevalo da se donosi u upravnom postupku te da nezadovoljni pojedinac protiv nje može izjaviti sva sredstva pravne zaštite. Međutim, to nigdje nije izričito određeno, slijedom čega je zadaća utvrditi pravnu prirodu ove odluke prepuštena sudskoj praksi i pravnoj doktrini.

Posljednji postupovni stadij dodjele zakupa na poljoprivrednom zemljištu predstavlja sklapanje ugovora s odabranim zakupoprimcem. Temeljem odluke o izboru najpovoljnije ponude sklapa se ugovor o zakupu odnosno ugovor o zakupu za ribnjake. Zakon o poljoprivrednom zemljištu propisuje da ovaj ugovor u pisanome obliku sklapaju ravnatelj Agencije u ime Republike Hrvatske i odabrani ponuditelj. U suprotnom ugovor neće imati pravni učinak. Zakon ujedno propisuje sadržaj toga ugovora. ${ }^{66}$ No, baš kao ni u svezi s odlukom o davanju poljoprivrednoga zemljišta u zakup, ničim ne ukazuje niti na njegovu pravnu prirodu. Iako Zakonom o poljoprivrednom zemljištu ugovor o zakupu poljoprivrednoga zemljišta nije utvrđen upravnim ugovorom, on svakako ima određene značajke koje za trajanja ugovornoga odnosa državi kao ugovornoj stranci daju značajna prava u odnosu na drugu stranu. Tako, primjerice, ovaj ugovor prije isteka roka na koji je sklopljen, subjekt javnoga prava može jednostrano raskinuti: ako zakupnik ne plati zakupninu do kraja rujna tekuće godine, osim u slučaju više sile, ili drugih nepredviđenih okolnosti koje nisu krivnja zakupnika; ako zakupnik ne koristi poljoprivredno zemljište u vlasništvu države kao dobar gospodar; ako zakupnik ne ostvaruje ciljeve Gospodarskog programa koji čini sastavni dio ugovora o zakupu, dvije godine uzastopno od dana sklapanja ugovora, osim u slučaju više sile; ako zakupnik

66 Članak 32. stavci 1. do 4. Zakona o poljoprivrednom zemljištu. Sukladno članku 36. istoga Zakona, takav ugovor obvezno treba sadržavati odredbe koje se odnose na: predmet zakupa, vrijeme trajanja zakupa, visinu i rok plaćanja zakupnine, prava i obveze zakupnika, namjenu korištenja zakupljenog zemljišta, odustanak od ugovora, razloge za raskid ugovora, dopustivost postavljanja gospodarskih objekata, pomoćnih uređaja i objekata za iskorištavanje zemljišta, uvjete zaštite prirode ako se poljoprivredno zemljište u cijelosti ili djelomično nalazi unutar područja ekološke mreže te usklađivanje katastarskog i zemljišnoknjižnog stanja. Sastavni dio ovoga ugovora čini i ranije spomenuti obrazac Gospodarskoga programa korištenja poljoprivrednoga zemljišta u vlasništvu države, koji je ponuditelj dostavio u okviru svoje ponude. Kako sklapanjem ugovora o zakupu za ribnjake zakupnik stječe pravo korištenja kopnenih voda radi uzgoja riba i drugih vodenih organizama pogodnih za gospodarski uzgoj za sve vrijeme trajanja zakupa, sukladno članku 37. stavak 2. istoga Zakona sastavni dio ovoga ugovora čine i posebni uvjeti korištenja voda koje izdaju Hrvatske vode sukladno posebnom propisu o vodama. Članak 47. stavci 5. i 7. propisuju određene posebnosti u odnosu na druga normativna rješenja sadržana u Zakonu o poljoprivrednom zemljištu. Kako, sukladno članku 47. ovoga Zakona, pri zakupu zajedničkih pašnjaka svaki odabrani ponuditelj dobiva u zakup fizički neodređeni dio zajedničkog pašnjaka u površini proporcionalnoj broju uvjetnih grla stoke kojih je vlasnik, odnosno proporcionalno broju uvjetnih grla stoke čiji su vlasnici članovi zadruge, svi zakupnici zajedničkog pašnjaka potom su obvezni sklopiti sporazum o korištenju zajedničkog pašnjaka koji im je dan u zakup, u roku od 30 dana od dana sklapanja ugovora o zakupu zajedničkog pašnjaka, radi utvrđivanja međusobnih prava i obveza zakupnika koja proizlaze s osnova korištenja zajedničkog pašnjaka. Ako zakupnici u propisanome roku ne sklope takav sporazum, ugovor o zakupu zajedničkog pašnjaka se raskida. 
obrađuje poljoprivredno zemljište suprotno odredbama sklopljenog ugovora; ako zakupnik daje zakupljeno zemljište u podzakup; ako zakupnik bez odobrenja zakupodavca izvrši investicijske radove na poljoprivrednom zemljištu koji prelaze granice uobičajenoga gospodarenja ili promijeni način korištenja poljoprivrednog zemljišta; ako zakupnik obavlja aktivnosti suprotno propisima o zaštiti prirode ili radnje koje imaju negativan utjecaj na bogatstvo ili stanje prirodnog područja te ako na bilo koji način ugrožava opstanak prirodnih vrijednosti; ili ako zakupnik ne iskrči poljoprivredno zemljište u vlasništvu države koje nije u funkciji poljoprivredne proizvodnje ili je obraslo višegodišnjim raslinjem u roku od dvije godine od dana uvođenja u posjed. ${ }^{67}$ Nesporno je kako postojanje bilo koje od ovdje propisanih pretpostavki utvrđuje Agencija te ako utvrdi da je ispunjena jednostrano, raskida ovaj ugovor. Iako je pravo jednostranoga raskida ugovora, koje proizlazi iz nadzornih prava ovoga tijela, bitno obilježje upravnoga ugovora, Zakon o poljoprivrednom zemljištu propisuje kako se na raskid ugovora o zakupu poljoprivrednog zemljišta u vlasništvu države koji nije uređen odredbama toga Zakona, primjenjuju opći propisi, tj. propisi građanskoga prava koji se primjenjuju na ugovore. ${ }^{68}$ Slijedom toga, ovaj ugovor smatra se ugovorom građanskoga prava. Pridavanjem tome ugovoru pravne prirode upravnoga ugovora, pravna zaštita poljoprivrednoga zemljišta, kao dobra od interesa za Republiku Hrvatsku, bila bi mnogo učinkovitija.

Može se zaključiti kako je pravna regulacija korištenja poljoprivrednoga zemljišta u vlasništvu države u Zakonu o poljoprivrednom zemljištu poprilično neujednačena i nekonzistentna. Mnoga postupovna i materijalna pitanja ovaj Zakon prepušta regulaciji podzakonskim aktima, koji nerijetko nepotrebno sadržavaju prepisane zakonske odredbe, a dio njih još nije niti donesen. Pravna priroda postupka davanja ovoga zemljišta u zakup, odluke o davanju u zakup i ugovora o zakupu također je nedorečena, čime se u praksi otvaraju ozbiljna pravna pitanja. Čini se da pravni okvir davanja poljoprivrednoga zemljišta u vlasništvu države na korištenje pojedincima zahtijeva nužnu doradu kojoj bi trebalo pristupiti što skorije.

\subsection{Pravni okvir davanja na korištenje šuma i šumskoga zemljišta u vlasništvu države}

U svezi s korištenjem šuma i šumskoga zemljišta u vlasništvu države, koje bi trebalo povećati gospodarsko iskorištavanje ovih površina, povećati im vrijednost te doprinijeti ostvarivanju određenih proračunskih prihoda, Zakon o šumama predviđa tri pravna instituta: osnivanje prava služnosti na šumama i šumskom zemljištu, osnivanje prava građenja na šumama i šumskom zemljištu te davanje ovoga zemljišta u zakup. Međutim, Zakon o šumama ove institute uređuje vrlo šturo. Samo tri od ukupno 93 članka ovoga Zakona posvećena su korištenju šuma i šumskoga zemljišta, prepuštajući podzakonskim propisima glavninu pravne regulacije njihova

67 Članak 38. stavak 4. Zakona o poljoprivrednom zemljištu.

68 Članak 42. Zakona o poljoprivrednom zemljištu. 
Dr. sc. Dario Đerđa: Pravni okvir korištenja nekih oblika financijske imovine u Republici Hrvatskoj Zbornik radova Pravnog fakulteta u Splitu, god. 54, 1/2017., str. 121.-158.

davanja na korištenje. Štoviše, i Zakon o šumama uredio je ove institute poprilično različito.

Vrlo malo pozornosti Zakon o šumama posvetio je osnivanju služnosti u šumi i na šumskom zemljištu. Zakon je jedino utvrdio okvirnu svrhu osnivanja prava služnosti na šumi ili na šumskome zemljištu u vlasništvu države ${ }^{69}$ te je odredio nadležnost za sklapanje ugovora o služnosti u šumi ili na šumskom zemljištu. ${ }^{70}$ Sve druge postupke i mjerila za osnivanje služnosti Zakon je prepustio Vladi Republike Hrvatske, na uređivanje uredbom. ${ }^{71}$ Koristeći ovu zakonsku ovlast, Vlada je donijela tri uredbe kojima je uredila osnivanje služnosti u tri različite svrhe: Uredbu o postupku i mjerilima za osnivanje prava služnosti na šumi i/ili šumskom zemljištu u vlasništvu Republike Hrvatske u svrhu eksploatacije mineralnih sirovina, Uredbu o postupku i mjerilima za osnivanje prava služnosti u šumi ili na šumskom zemljištu u vlasništvu Republike Hrvatske u svrhu obavljanja turističke djelatnosti te Uredbu o postupku i mjerilima za osnivanje služnosti u šumi ili na šumskom zemljištu u vlasništvu Republike Hrvatske u svrhu izgradnje vodovoda, kanalizacije, plinovoda, električnih vodova. ${ }^{72}$

Ove uredbe nemaju ujednačen način ni predmet regulacije. Tako, iako sve definiraju ovlaštenike prava služnosti, Uredba o postupku i mjerilima za osnivanje prava služnosti na šumi i/ili šumskom zemljištu u vlasništvu Republike Hrvatske u svrhu eksploatacije mineralnih sirovina utvrđuje maksimalne površine na kojima se može tražiti osnivanje služnosti, dok Uredba o postupku i mjerilima za osnivanje prava služnosti u šumi ili na šumskom zemljištu u vlasništvu Republike Hrvatske u svrhu obavljanja turističke djelatnosti, primjerice, propisuje svrhe u koje se može odobriti osnivanje ove služnosti. ${ }^{73} \mathrm{U}$ uredbama je različito uređen i način pokretanja

69 Člankom 57. stavak 1. Zakona o šumama propisano je kako se pravo služnosti u šumi ili na šumskom zemljištu može osnovati u svrhu izgradnje vodovoda, kanalizacije, plinovoda, električnih vodova, eksploatacije mineralnih sirovina, obavljanja turističke djelatnosti, uzgoja stoke i divljači. Naznačujući svrhu zasnivanja služnosti samo primjerično, Zakon nije zaključio katalog svrha u koje se pravo služnosti može osnovati.

70 Člankom 57. stavak 2. Zakona o šumama propisano je kako ugovor o služnosti u šumi ili na šumskom zemljištu u ime Republike Hrvatske sklapa ministar nadležan za poslove šumarstva, osim ugovora o služnosti radi eksploatacije mineralnih sirovina.

71 Članak 57. stavak 3. Zakona o šumama.

72 Uredba o postupku i mjerilima za osnivanje prava služnosti na šumi i/ili šumskom zemljištu u vlasništvu Republike Hrvatske u svrhu eksploatacije mineralnih sirovina, Narodne novine, br. 133/07 i 9/11, Uredba o postupku i mjerilima za osnivanje prava služnosti u šumi ili na šumskom zemljištu u vlasništvu Republike Hrvatske u svrhu obavljanja turističke djelatnosti, Narodne novine, br. 69/07 i Uredba o postupku i mjerilima za osnivanje služnosti u šumi ili na šumskom zemljištu u vlasništvu Republike Hrvatske u svrhu izgradnje vodovoda, kanalizacije, plinovoda, električnih vodova, Narodne novine, br. 108/06.

73 Vidi članak 2. stavak 2. te članak 3. Uredbe o postupku i mjerilima za osnivanje prava služnosti na šumi i/ili šumskom zemljištu u vlasništvu Republike Hrvatske u svrhu eksploatacije mineralnih sirovina, članke 2. i 3. Uredbe o postupku i mjerilima za osnivanje prava služnosti u šumi ili na šumskom zemljištu u vlasništvu Republike Hrvatske u svrhu obavljanja turističke djelatnosti te članak 2. stavak 2. Uredbe o postupku i mjerilima za osnivanje služnosti u šumi ili na šumskom zemljištu u vlasništvu Republike Hrvatske u svrhu izgradnje vodovoda, kanalizacije, plinovoda, električnih vodova. Bitno je naglasiti kako se osnivanje služnosti na šumama i šumskom zemljištu za obavljanje turističke djelatnosti odnosi samo na uređenje prostora, a ne obuhvaća izgradnju turističkih objekata. 
postupka za osnivanje prava služnosti. Tako se postupak osnivanja prava služnosti u svrhu eksploatacije mineralnih sirovina te u svrhu izgradnje vodovoda, kanalizacije, plinovoda i električnih vodova pokreće podnošenjem zahtjeva, a postupak osnivanja prava služnosti u svrhu obavljanja turističke djelatnosti objavom javnoga poziva. Niti tijelo kojemu se podnose ovi zahtjevi nije isto, pa se tako, kako stoji u uredbama, zahtjev za osnivanje služnosti u svrhu eksploatacije mineralnih sirovina podnosi Povjerenstvu za imovinu Vlade Republike Hrvatske, putem Središnjeg državnog ureda za upravljanje državnom imovinom, dok se kod osnivanja služnosti u svrhu izgradnje vodovoda, kanalizacije, plinovoda i električnih vodova podnosi Središnjem državnom uredu za upravljanje državnom imovinom. Sve uredbe propisuju sadržaj ovih zahtjeva odnosno prijedloga i priloge koji se uz njih obvezno prilažu, prilagođavajući ih specifičnostima koje se pri donošenju odluke trebaju uzeti u obzir. ${ }^{74} \mathrm{Za}$ razliku od postupaka propisanih za osnivanje služnosti u svrhu eksploatacije mineralnih sirovina te u svrhu izgradnje vodovoda, kanalizacije, plinovoda i električnih vodova, pri osnivanju prava služnosti u svrhu obavljanja turističke djelatnosti, zainteresirane osobe dostavljaju prijedloge na javni poziv Ministarstva poljoprivrede, po primitku kojih postupak odabira najpovoljnijega ponuditelja provodi stručno povjerenstvo koje imenuje ministar. ${ }^{75}$ Sve uredbe propisuju da odluku o osnivanju prava služnosti donosi Povjerenstvo za imovinu Vlade Republike Hrvatske. ${ }^{76}$ Kako je spomenuto Povjerenstvo za imovinu Vlade Republike Hrvatske prestalo djelovati 2011. godine, a više ne postoji niti Središnji državni ured za upravljanje državnom imovinom, nadležnost za zaprimanje zahtjeva te za donošenje odluke o osnivanju prava služnosti danas se određuje sukladno odredbama Zakona o upravljanju državnom imovinom. Sukladno ovim uredbama, različita tijela raspolažu ovlastima za sklapanje ugovora o osnivanju prava služnosti. Ugovor o osnivanju prava služnosti u svrhu eksploatacije mineralnih sirovina sklapa tijelo nadležno za raspolaganje imovinom Republike Hrvatske, tj. Državni ured za upravljanje državnom imovinom, dok ugovor o osnivanju prava služnosti u svrhu obavljanja turističke djelatnosti te ugovor o osnivanju prava služnosti u svrhu izgradnje vodovoda, kanalizacije, plinovoda i električnih vodova sklapa ministar poljoprivrede. ${ }^{77} \mathrm{U}$ svezi s analiziranim postupcima, na kraju se može primijetiti kako

74 Članak 2. Uredbe o postupku $i$ mjerilima za osnivanje prava služnosti na šumi i/ili šumskom zemljištu u vlasništvu Republike Hrvatske u svrhu eksploatacije mineralnih sirovina, članak 6. stavak 1. Uredbe o postupku i mjerilima za osnivanje prava služnosti u šumi ili na šumskom zemljištu u vlasništvu Republike Hrvatske u svrhu obavljanja turističke djelatnosti te članak 2. Uredbe o postupku i mjerilima za osnivanje služnosti u šumi ili na šumskom zemljištu u vlasništvu Republike Hrvatske u svrhu izgradnje vodovoda, kanalizacije, plinovoda, električnih vodova.

75 Članak 6. stavci 1. i 2. te članci 7. i 8. Uredbe o postupku i mjerilima za osnivanje prava služnosti u šumi ili na šumskom zemljištu u vlasništvu Republike Hrvatske u svrhu obavljanja turističke djelatnosti.

76 Članak 4. Uredbe o postupku i mjerilima za osnivanje prava služnosti na šumi i/ili šumskom zemljištu u vlasništvu Republike Hrvatske u svrhu eksploatacije mineralnih sirovina, članak 9. Uredbe o postupku i mjerilima za osnivanje prava služnosti u šumi ili na šumskom zemljištu u vlasništvu Republike Hrvatske, u svrhu obavljanja turističke djelatnosti te članak 3. Uredbe o postupku i mjerilima za osnivanje služnosti u šumi ili na šumskom zemljištu u vlasništvu Republike Hrvatske u svrhu izgradnje vodovoda, kanalizacije, plinovoda, električnih vodova.

77 Članak 4. te članak 6. stavak 1. Uredbe o postupku i mjerilima za osnivanje prava služnosti na šumi i/ili šumskom zemljištu u vlasništvu Republike Hrvatske u svrhu eksploatacije mineralnih sirovina, 
bi ovlaštenik prava služnosti zasnivanje ovoga prava trebao temeljiti postojanjem kojeg drugoga već stečenoga prava te nije jasno je li osnivanje služnosti u svrhu obavljanja turističke djelatnosti temeljem javnoga poziva uopće opravdano. Ujedno, nije jasno niti iz kojega se razloga razlikuju ovlaštenici za sklapanje ugovora o osnivanju prava služnosti, kao ni jesu li uopće nužne tri različite uredbe za uređenje osnivanja prava služnosti na istome dobru, a u različite svrhe. Ono što Zakon i uredbe također ostavljaju otvorenim jest pitanje pravne prirode odluke o osnivanju služnosti te ugovora o osnivanju prava služnosti, čime pravni režim ovih akata nije potpuno jasan.

Zakon o šumama vrlo šturo propisuje i osnivanje prava građenja u šumama i na šumskom zemljištu u vlasništvu države. Precizno utvrđuje svrhu osnivanja prava građenja na ovome zemljištu, propisujući kako je pravo građenja dopušteno osnovati u svrhu izgradnje golf-igrališta, kampa i objekata čija je gradnja prema prostornom planu predviđena izvan građevinskog područja. ${ }^{78}$ Jednako kao i u slučaju osnivanja prava služnosti, utvrđuje nadležnost za sklapanje ugovora o osnivanju prava građenja te postavlja ograničenje osnivanja ovoga prava samo na šumu i šumsko zemljište koje je Ministarstvo poljoprivrede proglasilo šumom s posebnom namjenom u svrhu izgradnje golf-igrališta i kampa, na temelju odobrenog programa za gospodarenje šumama s posebnom namjenom..$^{79}$ Međutim, postupak i mjerila za osnivanje prava građenja Zakon je također prepustio na regulaciju Vladi Republike Hrvatske uredbom. ${ }^{80}$ Temeljem ove zakonske ovlasti, Vlada Republike Hrvatske donijela je Uredbu o osnivanju prava građenja na šumama i šumskom zemljištu u vlasništvu Republike Hrvatske. ${ }^{81}$ Ova Uredba određuje nositelja prava građenja, za kojega izričito utvrđuje da raspolaže ovlastima i dužnostima plodouživatelja. Najprije propisuje postupak proglašavanja šume i šumskog zemljišta šumom s posebnom namjenom, što predstavlja stanoviti vid postupka koji prethodi postupku osnivanja prava građenja. Sukladno Uredbi, postupak osnivanja prava građenja u pravilu pokreće Ministarstvo poljoprivrede javnim prikupljanjem ponuda. Iznimno, ovo pravo može se osnovati i neposrednom pogodbom, ali samo u slučajevima utvrđenima posebnim propisima. Uredba detaljno propisuje što sve mora sadržavati poziv za prikupljanje ponuda te način objave ovoga poziva. Također propisuje što je ponudi sve potrebno priložiti te način obračuna jamčevine koju uz ponudu treba uplatiti. Ponude razmatra posebno povjerenstvo za prikupljanje ponuda koje sukladno kriterijima utvrđenima u Uredbi izrađuje prijedlog odluke o odabiru najpovoljnijeg ponuditelja i dostavlja ih ministru poljoprivrede. Uredba

članak 12. Uredbe o postupku i mjerilima za osnivanje prava služnosti u šumi ili na šumskom zemljištu u vlasništvu Republike Hrvatske u svrhu obavljanja turističke djelatnosti te članak 5. Uredbe o postupku i mjerilima za osnivanje služnosti u šumi ili na šumskom zemljištu u vlasništvu Republike Hrvatske u svrhu izgradnje vodovoda, kanalizacije, plinovoda, električnih vodova.

78 Članak 57.a stavak 1. Zakona o šumama.

79 Sukladno članku 57.a stavak 2. Zakona o šumama, ugovor o pravu građenja na šumama i šumskom zemljištu u vlasništvu države u ime Republike Hrvatske sklapa ministar poljoprivrede.

80 Članak 57.a stavak 5. Zakona o šumama.

81 Uredba o osnivanju prava građenja na šumama i šumskom zemljištu u vlasništvu Republike Hrvatske, Narodne novine, br. 61/16. 
nadalje propisuje da odluku o odabiru najpovoljnijeg ponuditelja kao nositelja prava građenja, na temelju prijedloga povjerenstva, donosi ministar poljoprivrede, kao i sadržaj ove odluke. Ujedno izričito propisuje kako ova odluka nije upravni akt. ${ }^{82}$ Ovdje se Vlada očito povela izričitim odredbama Zakona o poljoprivrednom zemljištu koje utvrđuju da odluka kojom se odlučuje o vlasničkim i drugim stvarnim pravima na poljoprivrednom zemljištu u vlasništvu države nije upravni akt. ${ }^{83}$ Međutim, ovakvim određenjem značajno su oštećeni ponuditelji koji se javljaju u ovim postupcima, jer nemaju adekvatnu postupovnu zaštitu koju bi imali propisivanjem ovoj odluci pravne prirode upravnoga akta, što će se sigurno pokazati značajnom manom ove pravne regulacije. Temeljem odluke o odabiru najpovoljnijeg ponuditelja, lokacijske dozvole te uplaćene naknade za pravo građenja, ugovor o pravu građenja s odabranim ponuditeljem u ime Republike Hrvatske sklapa ministar poljoprivrede, u roku od 30 dana od pribavljenog pozitivnog mišljenja nadležnog državnog odvjetništva. Uredba ujedno propisuje i sadržaj ovoga ugovora, ${ }^{84}$ no opet ne propisuje njegovu pravnu prirodu. Kako Uredba izričito propisuje da odluka o odabiru najpovoljnijeg ponuditelja nije upravni akt, jasno je kako se niti ovaj ugovor ne može smatrati upravnim ugovorom.

Konačno, Zakon o šumama vrlo šturo uređuje i postupak davanja šumskih zemljišta u zakup. Sukladno Zakonu, davanje ovih zemljišta u zakup dopušteno je samo do njihova privođenja namjeni koja je određena šumskogospodarskim planovima. U svezi sa zakupom šumskoga zemljišta Zakon još jedino propisuje da je prije sklapanja ugovora o zakupu potrebno pribaviti mišljenje o pravnoj valjanosti ovoga ugovora od nadležnoga državnoga odvjetništva. Način i kriterije davanja u zakup šumskoga zemljišta zakonodavac je također prepustio Vladi koja ova pitanja treba urediti uredbom. ${ }^{85}$ Vlada je donijela Uredbu o načinu i kriterijima za davanje u zakup šumskog zemljišta u vlasništvu Republike Hrvatske ${ }^{86}$ koja, pored postupovnih, sadrži i neke materijalne odredbe, kao npr. namjenu davanja ovoga zemljišta u zakup te njegovu zabranu davanja u podzakup. ${ }^{87}$ Uredba postavlja statusne kriterije ovlaštenika zakupa te najdulji rok na koji se zemljište može dati u zakup. Sukladno ovoj Uredbi, postupak davanja šumskoga zemljišta u zakup pokreće se objavom javnoga poziva za prikupljanje ponuda, koji se objavljuje u javnim glasilima i na mrežnim stranicama Ministarstva poljoprivrede. Postupak

82 Članci 2. te 5. do 15. Uredbe o osnivanju prava građenja na šumama $i$ šumskom zemljištu $u$ vlasništvu Republike Hrvatske.

83 Članak 26. Zakona o poljoprivrednom zemljištu.

84 Članak 19. stavak 2. i članak 22. Uredbe o osnivanju prava građenja na šumama $i$ šumskom zemljištu u vlasništvu Republike Hrvatske.

85 Članak 58. Zakona o šumama.

86 Uredba o načinu i kriterijima za davanje u zakup šumskog zemljišta u vlasništvu Republike Hrvatske, Narodne novine, br. 76/14.

87 Tako se, sukladno članku 3. te članku 10. stavak 2. ove Uredbe, šumsko zemljište može dati u zakup radi korištenja u svrhu: odmora, rekreacije i sporta (trim-staze, staze za jahanje, privremeni sportski tereni, stolovi i klupe za odmor i sl.); pašarenja i žirenja; postavljanja pomičnih naprava, reklamnih panoa, štandova, montažno-demontažnih tendi te privremenih kioska i drugih građevina gotove konstrukcije, građevinske (bruto) površine do $15 \mathrm{~m} 2$. 
odabira najboljeg ponuditelja, sukladno kriterijima koje utvrđuje Uredba, provodi stručno povjerenstvo što ga imenuje ministar poljoprivrede. Uredba postavlja primarni kriterij izbora, ali i sekundarni koji će se primijeniti ako dvije ili više ponuda, sukladno primarnome kriteriju, budu jednako ocijenjene. Povjerenstvo odabire najpovoljnijeg ponuditelja te predlaže ministru donošenje odluke. Odluku o davanju u zakup šumskoga zemljišta donosi ministar poljoprivrede. Po ishođenju pozitivnoga mišljenja nadležnog županijskog državnog odvjetništva o pravnoj valjanosti nacrta ugovora o zakupu, ministar poljoprivrede s odabranim najpovoljnijim ponuditeljem sklapa ugovor o zakupu. ${ }^{88}$

Iako Uredba ne propisuje pravnu prirodu ugovora o zakupu, nesporno je kako i prema ovome ugovoru zakupodavac, tj. Republika Hrvatska, raspolaže snažnijim ovlastima u ugovornome odnosu. Tako, ako zakupnik ne koristi šumsko zemljište sukladno ugovoru o zakupu, ne nadoknadi štetu nastalu korištenjem šumskog zemljišta protivno ugovoru o zakupu, ne čuva zakupljenu nekretninu te je očito da je po prestanku ugovora o zakupu neće moći vratiti u stanju u kojem ju je preuzeo, ne plaća zakupninu sukladno ugovoru o zakupu ili ako nanosi štetu okolnoj šumi i šumskom zemljištu, zakupodavac je ovlašten jednostrano raskinuti ovaj ugovor. ${ }^{89}$ Slijedom toga, država i ovdje raspolaže pravom nadzora te snažnim jednostranim ovlastima u slučaju kada ocijeni da zakupoprimac ne poštuje odredbe ugovora o zakupu. No, niti ovaj ugovor prema pravnoj prirodi nije utvrđen upravnim ugovorom čime je pravna zaštita šumskoga zemljišta kao dobra od interesa za Republiku Hrvatsku također učinjena slabijom negoli bi to trebao biti slučaj. ${ }^{90}$

Iz navedenoga dade se zaključiti kako se šume i šumsko zemljište mogu koristiti temeljem istih instituta kao i poljoprivredno zemljište. Međutim, postupci davanja ovoga zemljišta na korištenje značajno se razlikuju od davanja na korištenje poljoprivrednoga zemljišta. Podnormiranost mehanizama korištenja šuma i šumskoga zemljišta u Zakonu o šumama te davanje velike slobode reguliranja ovih postupaka Vladi Republike Hrvatske, kao i kriterija koji će se u njima koristiti, svakako se može ocijeniti nedostatkom pravne regulacije. Ove uredbe sadrže brojne razlike u vođenju postupaka koje dovode do pravne nesigurnosti osoba zainteresiranih koristiti šume i šumsko zemljište u vlasništvu države. Konačno, posebna zamjerka regulaciji korištenja šuma i šumskih zemljišta u vlasništvu države svakako se može uputiti isključivanju javnopravnih instrumenata, čime se oslabljuje položaj javne vlasti u upravljanju i zaštiti ovoga važnoga prirodnoga resursa.

88 Članci 4. do 7. te članak 9. stavci 1. i 2. Uredbe o načinu i kriterijima za davanje u zakup šumskog zemljišta u vlasništvu Republike Hrvatske.

89 Članak 10. stavci 2. do 4. Uredbe o načinu i kriterijima za davanje u zakup šumskog zemljišta $u$ vlasništvu Republike Hrvatske.

90 Ovdje je još zanimljivo istaknuti kako se sukladno članku 12. Uredbe o načinu i kriterijima za davanje u zakup šumskog zemljišta u vlasništvu Republike Hrvatske, na zahtjev zakupnika i uz pozitivno mišljenje Hrvatskih šuma d.o.o., ugovor o zakupu može obnavljati za isto razdoblje i pod istim uvjetima, ukoliko je u proteklom razdoblju zakupnik uredno i na vrijeme ispunjavao sve obveze preuzete ugovorom o zakupu ili do privođenja ovoga područja namjeni određenoj šumskogospodarskim planovima. Zahtjev za obnovom ugovora o zakupu zakupnik podnosi Ministarstvu poljoprivrede najranije u zadnjoj godini trajanja zakupa, a najkasnije 60 dana prije isteka ugovora o zakupu. 


\subsection{Pravni okvir davanja na korištenje javnoga vodnoga dobra u javnoj uporabi}

Konačno, Zakon o vodama korištenje javnoga vodnoga dobra za gospodarske i osobne potrebe uređuje samo jednim od 263 članaka. Ovaj Zakon kao oblike privatnoga korištenja javnoga vodnoga dobra propisuje najam, zakup, služnost i građenje. Na dijelu javnog vodnog dobra koji je dan na korištenje nekoj osobi može se svim drugim osobama ograničiti ili potpuno isključiti njegova uporaba, međutim samo ako takvo pravo ne utječe na ostvarivanje namjena vodnoga dobra. ${ }^{91}$ Postupovni režim davanja javnoga vodnoga dobra u najam, zakup, služnost i građenje radi ostvarenja gospodarskih, odnosno osobnih potreba pojedinaca, Zakonom o vodama određen je vrlo šturo. Međutim, istovremeno je postavljen i vrlo precizno. Štoviše, korištenje javnog vodnog dobra u javnoj uporabi nije detaljnije razrađivano čak niti podzakonskim propisima. Zakon o vodama propisuje da se davanje javnoga vodnoga dobra u najam ili zakup, odnosno osnivanje prava služnosti i prava građenja na ovome zemljištu zasniva na odluci. Utvrđuje donositelja ove odluke te određuje njezinu pravnu prirodu, jednostavno propisujući kako ovu odluku donose Hrvatske vode u upravnom postupku. Time Zakon o vodama rješava sve dvojbe koje se tiču postupovnog režima donošenja odluke o davanju javnoga vodnoga dobra na korištenje privatnim osobama za gospodarske i osobne potrebe. Iz navedenoga proizlazi kako je odluka kojom se odlučuje o davanju javnoga vodnoga dobra u javnoj uporabi u najam, zakup, služnost ili građenje upravni akt, slijedom čega se na postupak njezina donošenja, ali i u pogledu pravne zaštite potencijalnih ponuditelja, primjenjuju odredbe Zakona o općem upravnom postupku. Zakon još propisuje da na ovu odluku Hrvatskim vodama - pravnoj osobi za upravljanje vodama, prethodno mišljenje daje Državni ured za upravljanje državnom imovinom, te da se protiv ove odluke može izjaviti žalba Ministarstvu poljoprivrede. Po donošenju odluke, Hrvatske vode u ime Republike Hrvatske i odabrani ponuditelj sklapaju ugovor o najmu, zakupu, služnosti i pravu građenja na javnom vodnom dobru..$^{92}$ Jedino pitanje koje se po analizi ovih odredbi otvara jest na koji se način uopće pokreće postupak davanja javnoga vodnoga dobra u najam ili zakup, odnosno na koji se način pokreće postupak osnivanja prava služnosti i prava građenja na javnom vodnom dobru u javnoj uporabi. Odgovor na ovo pitanje nalazi se u Odluci o visini naknade najma, zakupa, služnosti i građenja na javnom vodnom dobru ${ }^{93}$ koja propisuje kako se pravo zakupa zasniva u postupku pokrenutom javnim natječajem, a pravo najma, služnosti i građenja zasniva se na neposredni zahtjev stranke. Iznimno, kada pravo

91 Javno vodno dobro ranije se moglo koristiti i putem koncesije. Danas se, sukladno članku 163. te članku 171. stavci 1. do 3. Zakona o vodama, koncesije daju jedino za gospodarsko korištenje voda te za javne usluge $\mathrm{i}$ javne radove, osim za obavljanje djelatnosti javne vodoopskrbe $\mathrm{i}$ javne odvodnje. $\mathrm{O}$ prijašnjem pravnom uređenju koncesija na javnom vodnom dobru, više vidi u Lukačević-Subotić, op. cit., str. 11-14. Koncesija je osnovni način korištenja voda koji prelazi oblike općega korištenja, dok se vode iznimno mogu koristiti temeljem vodopravne dozvole. O ovome Jug, op. cit., str. 284.

92 Članak 16. stavci 3. i 4. Zakona o vodama.

93 Odluka o visini naknade najma, zakupa, služnosti i građenja na javnom vodnom dobru, Narodne novine $89 / 10$ i $88 / 11$. 
zakupa uključuje i zasnivanje prava građenja, ovo pravo dodjeljuje se u postupku pokrenutome na neposredni zahtjev stranke. ${ }^{94}$

Nesporno je da je, za razliku od Zakona o poljoprivrednom zemljištu i Zakona o šumama, Zakon o vodama uredio postupak ustupanja zemljišta na korištenje koje je od interesa za Republiku Hrvatsku privatnoj osobi na vrlo jednostavan, ali i pravno egzaktan način. Ovaj Zakon, unatoč malom broju odredbi koje je posvetio ovim pitanjima, definirao je manje-više sva ključna pitanja davanja ovih prostora na korištenje. Odredio je tijelo nadležno odlučiti o davanju nekoga od ovih zemljišta na korištenje privatnim osobama te pravnu prirodu akta kojim se to čini. Time je precizno ukazao na pravni režim donošenja ove odluke, od pitanja koja se odnose na pokretanje postupka, utvrđivanje činjenica pa sve do odlučivanja o meritumu i izrade same odluke. Na takav je način ujedno precizno utvrdio mehanizme pravne zaštite zainteresiranih osoba koje se mogu javiti u ovome postupku. S druge strane, oslobodio je pravni sustav velikog broja prepisanih odredbi te različitih pravnih režima koji se u svezi sa sličnim pravnim institutima javljaju na poljoprivrednom zemljištu u vlasništvu države te u šumi ili na šumskom zemljištu u vlasništvu države, na taj način doprinijevši brzini odlučivanja, predvidivosti postupaka i sigurnosti stranaka, a svime time i pravnoj sigurnosti.

\section{ZAKLJUČAK}

Po analizi pravnoga režima korištenja poljoprivrednoga zemljišta u vlasništvu države, šuma i šumskoga zemljišta u vlasništvu države te javnoga vodnoga dobra u javnoj uporabi može se zaključiti kako jedinstveni opći pravni okvir korištenja ovih zemljišta u Hrvatskoj ne postoji. Takav okvir na najopćenitiji način ne postavlja niti zakon koji na općenit način uređuje upravljanje državnom imovinom, tj. Zakon o upravljanju državnom imovinom, jer unatoč tome što se on odnosi i na upravljanje nekretninama čiji je vlasnik Republika Hrvatska i koje su upisane u Središnji registar državne imovine, upravljanje ovim dobrima izričito je izuzeto iz primjene toga Zakona. ${ }^{95}$ Kako sukladno ovome Zakonu korištenje državne imovine podrazumijeva uporabu i ubiranje plodova ili koristi koje državna imovina daje, bez prava otuđenja ili opterećenja, ${ }^{96}$ jasno je kako bi davanje ovih zemljišta na korištenje na općenit način trebalo biti uređeno i ovim Zakonom, slijedom čega se ispravnost njihova izričitog isključivanja iz dosega toga Zakona može propitivati. Štoviše, ovaj Zakon pod raspolaganjem nekretninama u vlasništvu Republike Hrvatske podrazumijeva između ostaloga i davanje ovih nekretnina u zakup ili najam te osnivanje prava građenja i osnivanje prava služnosti na tim nekretninama, a ti instituti javljaju se i u ranije analiziranim zakonima. Međutim, o nadležnosti, postupcima te pravnoj prirodi

\footnotetext{
94 Članak 9. Odluke o visini naknade najma, zakupa, služnosti i građenja na javnom vodnom dobru.

95 Članak 3. točka 1. te članak 60. stavak 2. Zakona o upravljanju državnom imovinom.

96 Članak 3. stavak 4. Zakona o upravljanju državnom imovinom.
} 
akata koji se donose pri davanju na korištenje zemljišta u državnom vlasništvu ovaj Zakon na žalost ne propisuje gotovo ništa.

Zakon o upravljanju državnom imovinom tijelima nadležnima za raspolaganje državnim nekretninama jedino postavlja obvezu postupanja prema Strategiji upravljanja i raspolaganja državnom imovinom, prema Planu upravljanja, prema tome Zakonu i prema posebnim propisima. Propisuje kako se postupci raspolaganja ovim nekretninama pokreću raspisivanjem javnog nadmetanja, koje se provodi kao javno raspolaganje prema unaprijed objavljenim uvjetima ili javnim prikupljanjem ponuda koje se provodi kao poziv na predaju ponuda upućenom neodređenom ili određenom krugu osoba, i to prema unaprijed određenim uvjetima. Iz Zakona ujedno proizlazi da se ugovor o korištenju ovih nekretnina sklapa s ponuditeljem koji ispunjava uvjete i ponudi najvišu cijenu iznad početne cijene. Iznimka od ovih pravila uspostavljena je jedino za osnivanje prava služnosti, koje se može osnovati i temeljem prijedloga zainteresirane osobe, osim ako je posebnim propisom utvrđeno drukčije raspolaganje. ${ }^{97}$

Međutim, Zakon o upravljanju državnom imovinom ne određuje pravnu prirodu odluke koja se donosi u postupku davanja ovih nekretnina na korištenje niti pravnu prirodu ugovora koji se temeljem takve odluke sklapa. Stoga se može ustvrditi da se korištenje ovih nekretnina u bitnome uređuje pojedinačnim pravnim režimima koji se primjenjuju u svakom upravnom području, slijedom čega je opći pravni režim ovih postupaka vrlo skromno uređen. No, pravni režimi davanja poljoprivrednoga zemljišta u vlasništvu države, šuma i šumskoga zemljišta u vlasništvu države i javnoga vodnog dobra u javnoj uporabi vrlo su neujednačeni, kako po pitanju pravne prirode ovih postupaka, njihova pokretanja, pravila postupka, tako i nadležnosti za donošenje odluka. Zakon o poljoprivrednom zemljištu primjerice predviđa davanje poljoprivrednoga zemljišta u vlasništvu države, ribnjaka, zajedničkih pašnjaka i neizgrađenoga građevinskog zemljišta koje je po uporabnom svojstvu poljoprivredno zemljište u zakup, zasnivanje na poljoprivrednom zemljištu u vlasništvu države prava služnosti i prava građenja te davanje ovoga zemljišta na korištenje bez naknade. Zakon o šumama omogućuje korištenje šuma i šumskoga zemljišta putem osnivanja prava služnosti i prava građenja te putem zakupa, dok Zakon o vodama propisuje da se javno vodno dobro može dati na korištenje putem najma, zakupa, prava služnosti i prava građenja. Dakle, jasno je da svi ovi zakoni propisuju tri temeljna načina korištenja ovih zemljišta koji su po funkciji različiti. To su zakup, pravo služnosti i pravo građenja. Ostali načini korištenja ovih zemljišta čine se sporednima.

Ugovorom o zakupu nekretnine u vlasništvu države Vlada Republike Hrvatske obvezuje se predati privatnoj osobi određenu nekretninu na korištenje, a ova se osoba zauzvrat obvezuje plaćati utvrđenu zakupninu. Takvo zemljište može koristiti samo na način određen ugovorom o zakupu i u skladu s namjenom toga zemljišta. Ova osoba ujedno odgovara za svu štetu koja nastane korištenjem zakupljenoga

97 Članak 48. stavak 2. članak 49. stavci 1. i 2., članak 5. stavak 5. Zakona o upravljanju državnom imovinom. 
zemljišta protivno ugovoru ili namjeni, bez obzira na to je li ovo zemljište koristila sama ili pak osoba koja radi po njezinu nalogu, podzakupnik ili koja druga osoba kojoj je omogućila zasebno ga koristiti. Na sva pitanja zakupa toga zemljišta koja nisu uređena posebnim zakonom supsidijarno se primjenjuju odredbe Zakona o obveznim odnosima ${ }^{98}$ koje se odnose na ugovor o zakupu. ${ }^{99}$

Svrha prava građenja jest odvojiti vlasništvo zgrade izgrađene na zemljištu od vlasništva zemljišta. Pravo građenja ovlašćuje svojeg nositelja na njemu sagraditi odnosno imati zgradu koja pravno nije spojena sa zemljištem na kojem je de facto izgrađena i koja je u tuđem vlasništvu, što znači da je, dok ovo pravo traje, jedna osoba vlasnik zgrade, a druga vlasnik zemljišta, nakon čega se zgrada pravno spaja sa zemljištem i čini jedinstvenu nekretninu. Time pravo građenja omogućuje vlasniku zemljišta zadržati u svojem vlasništvu zemljište na kojem druga osoba gradi građevinski objekt te od ove osobe ubirati naknadu koju ona plaća za osnovano pravo. Ono predstavlja iznimku od načela jedinstva nekretnine odnosno zemljišta i zgrade na kojem se temelji opće stvarnopravno uređenje uspostavljeno Zakonom o vlasništvu i drugim stvarnim pravima. ${ }^{100}$

Svrha prava služnosti ogleda se u ograničavanju prava vlasnika neke nekretnine na način da on mora trpjeti ili propuštati da se ovlaštenik služnosti njome na neki način koristi. Služnost se može sastojati u tome da ovlaštenik služnosti na tuđoj nekretnini izvršava neke radnje, da se njome služi, da iz nje izvlači plodove ili čak u tome da on sam ništa ne poduzima, ali da se zbog njega na toj nekretnini održava postojeće stanje. S druge strane, vlasnik poslužne nekretnine uvijek je izložen trpljenju ili propuštanju neke radnje. ${ }^{101}$

Razvidno je kako zakup odnosno najam, pravo služnosti i pravo građenja imaju različite svrhe koje mogu privatnim osobama omogućiti korištenje poljoprivrednoga zemljišta u vlasništvu države, šuma i šumskoga zemljišta u vlasništvu države te javnoga vodnoga dobra u javnoj uporabi upravo na način koji im omogućuje najoptimalnije gospodarski koristiti ova dobra. Međutim, problem pravnoga okvira korištenja ovih zemljišta ogleda se u neujednačenoj pravnoj regulaciji sadržanoj u zakonima koji uređuju upravljanje i korištenje ovim zemljištima. Zakonska regulacija mehanizama korištenja ovih zemljišta u pravilu je štura i nepotpuna te precizno ne utvrđuje postupak stjecanja ovih prava. Poseban problem ogleda se u prepuštanju zakonodavca brojna postupovna pitanja urediti podzakonskim propisima Vlade i resornih ministarstava.

Stoga bi za državna tijela, ali i za privatne poduzetnike, najbolje bilo kada bi se zajednička pitanja postupaka davanja na korištenje ovih nekretnina uredila zajedničkim postupovnim pravilima sadržanima u općem zakonu, dok bi se posebnim

98 Zakon o obveznim odnosima, Narodne novine, br. 35/05, 41/08, 125/11 i 78/15.

99 Jedina razlika između ugovora o zakupu ili ugovora o najmu koje predviđa Zakon o vodama, ogleda se u okolnosti hoće li uz zasebno korištenje ovoga zemljišta korisnik imati pravo i ubiranja plodova, kada se radi o zakupu, ili ne, kada se radi o najmu. Aviani, op. cit., str. 145. te Jelčić, op. cit., str. 7-8.

${ }^{100}$ Gavella, Nikola, Stvarno pravo, Informator, Zagreb, 1998., str. 697. i Frković, op. cit., str. 10.

${ }^{101}$ Gavella, Stvarno, op. cit., str. 631. 
pravnim normama sadržanima u zakonima koji uređuju pojedina upravna područja ova pravila mogla jedino nadopuniti sukladno specifičnostima posebnog upravnog područja. Postupci davanja na korištenje ovih nekretnina trebali bi biti ujednačeni i maksimalno pojednostavljeni. Ovdje se može poći dobrim primjerom Zakona o vodama koji kratko, ali precizno utvrđuje postupak davanja na korištenje javnoga vodnog dobra. Naravno da treba respektirati specifičnosti pojedinih instituta, pa se tako primjerice postupak osnivanja služnosti treba moći pokrenuti na zahtjev zainteresirane osobe, dok bi se drugi postupci u pravilu trebali pokretati pozivom za javno nadmetanje. Nesporno je i kako sadržaji specifičnih zahtjeva i ponuda trebaju biti propisani zakonom, a ne podzakonskim propisima, baš kao što zakonom trebaju biti propisani i kriteriji odabira te statusne pretpostavke kojima moraju udovoljiti potencijalni ugovaratelji. Iako se nadležnost za donošenje odluka o davanju ovih zemljišta na korištenje i sklapanje ugovora o korištenju ovih zemljišta može povjeriti različitim tijelima, nije učinkovito formirati pojedina povjerenstva za vođenje postupka, koja zatim nadležnim tijelima samo predlažu donošenje odluka, posebno s obzirom na višegodišnju recesiju i proračunski deficit prisutan u Republici Hrvatskoj. Konačno, bilo bi izuzetno korisno, također po uzoru na Zakon o vodama, propisati da je odluka o davanju u zakup ili najam, osnivanje prava služnosti i prava građenja upravni akt, kako bi se na postupak donošenja ove odluke primijenile postupovne odredbe Zakona o općem upravnom postupku. Time bi se zainteresiranim osobama u postupku davanja na korištenje ovih zemljišta ujedno osigurala i adekvatna pravna zaštita, uključujući i pravo pokretanja upravnoga spora. Konačno, svakako bi valjalo razmisliti o tome bi li ugovore o zakupu i najmu, odnosno osnivanju prava služnosti ili prava građenja trebalo utvrditi upravnim ugovorima.

Unošenjem odredbi naznačenoga sadržaja u jedinstveni Zakon o upravljanju državnom imovinom ili ujednačavanjem ovih odredbi kroz zakone koji uređuju pojedina upravna područja stvorio bi se kvalitetan pravni okvir za davanje na korištenje državnih zemljišta zainteresiranim osobama, čime bi se ova zemljišta stavila u gospodarsku funkciju i time pridonijela gospodarskom razvoju Republike Hrvatske.

\section{Pravni izvori}

1. Izvješće o stanju u prostoru Republike Hrvatske 2008.-2012., Narodne novine, br. 61/13.

2. Odluka o visini naknade najma, zakupa, služnosti i građenja na javnom vodnom dobru, Narodne novine 89/10. i 88/11.

3. Pravilnik o dokumentaciji potrebnoj za raspisivanje javnog poziva za zakup, zakup za ribnjake i zamjenu poljoprivrednog zemljišta u vlasništvu Republike Hrvatske, Narodne novine, br. 84/13. i 45/14.

4. Uredba o пас̌inu i kriterijima za davanje u zakup šumskog zemljišta u vlasništvu Republike Hrvatske, Narodne novine, br. 76/14. 
5. Pravilnik o načinu i uvjetima za podnošenje zahtjeva za raspisivanje javnog poziva te kriterijima za dodjelu u zakup zajedničkih pašnjaka u vlasništvu Republike Hrvatske, Narodne novine, br. 68/15.

6. Uredba o osnivanju prava građenja na šumama $i$ šumskom zemljištu u vlasništvu Republike Hrvatske, Narodne novine, br. 61/16.

7. Uredba o postupku i mjerilima za osnivanje prava služnosti na šumi i/ili šumskom zemljištu u vlasništvu Republike Hrvatske u svrhu eksploatacije mineralnih sirovina, Narodne novine, br. 133/07. i 9/11.

8. Uredba o postupku i mjerilima za osnivanje služnosti u šumi ili na šumskom zemljištu u vlasništvu Republike Hrvatske u svrhu izgradnje vodovoda, kanalizacije, plinovoda, električnih vodova, Narodne novine, br. 108/06.

9. Uredba o postupku i mjerilima za osnivanje prava služnosti u šumi ili na šumskom zemljištu u vlasništvu Republike Hrvatske u svrhu obavljanja turističke djelatnosti, Narodne novine, br. 69/07.

10. Pravilnik o postupku javnog nadmetanja za utvrdivanje najpovoljnijeg ponuditelja na javnom pozivu za dodjelu poljoprivrednog zemljišta u vlasništvu Republike Hrvatske u zakup i zakup za ribnjake, Narodne novine, br. 120/13. i 98/15.

11. Uredba o osnivanju prava građenja i prava služnosti na nekretninama u vlasništvu Republike Hrvatske, Narodne novine, br. 10/14. i 95/15.

12. Ustav Republike Hrvatske, Narodne novine, br. 56/90, 135/97, 113/00, 28/01, 76/10 i 5/14.

13. Zakon o cestama, Narodne novine, br. 84/11, 22/13, 54/13, 148/13 i 92/14.

14. Zakon o obveznim odnosima, Narodne novine, br. 35/05, 41/08, 125/11 i $78 / 15$.

15. Zakon o općem upravnom postupku, Narodne novine, br. 47/09.

16. Zakon o poljoprivrednom zemljištu, Narodne novine, br. 39/13 i 48/15.

17. Zakon o šumama, Narodne novine 140/05, 82/06, 129/08, 80/10, 124/10, 25/12, 68/12, 148/13 i 94/14.

18. Zakon o upravljanju državnom imovinom, Narodne novine, br. 94/13 i $18 / 16$.

19. Zakon o vlasništvu i drugim stvarnim pravima, Narodne novine, br. 91/96, 68/98, 137/99, 22/00, 73/00, 114/01, 79/06, 141/06, 146/08, 38/09, 153/09, 90/10, 143/12 i 152/14.

20. Zakon o vodama, Narodne novine, br. 153/09, 63/11, 130/11, 56/13 i $14 / 14$.

21. Zakon o željeznici, Narodne novine, br. 94/13 i 148/13.

\section{Literatura}

1. Antoniolli, Walter, Koja, Friedrich, Allgemeines Verwaltungsrecht, Manzsche Verlags- und Universitätsbuchhandlung, Wien, 1996. 
2. Auby, Jean-Marie, Bonn, Pierre, Droit administratif des biens, Dalloz, Paris, 1995.

3. Aviani, Damir, „Zasebno korištenje opće-uporabljivih dobra u Hrvatskoj: dometi i ograničenja“, Zbornik radova Pravnog fakulteta u Splitu, god. 46, br. 1, 2009.

4. Babac, Branko, Upravno pravo, Pravni fakultet u Osijeku, Osijek, 2004.

5. Belaj, Vlado, „Posebno stvarnopravno uređenje za poljoprivredna zemljišta“, Stvarno pravo - posebna stvarna uređenja, Narodne novine, Zagreb, 2011.

6. Belaj, Vlado, „Posebno stvarnopravno uređenje za šume i šumska zemljišta“, Stvarno pravo - posebna pravna uređenja, Narodne novine, Zagreb, 2011.

7. Borković, Ivo, „Javno dobro (domaine public) u francuskoj teoriji upravnog prava“, Zbornik radova Pravnog fakulteta u Splitu, god. 40., br. 71-72, 2003.

8. Borković, Upravno pravo, Narodne novine, Zagreb, 2002.

9. Caringella, Francesco, Il Diritto Amministrativo, Edizioni giuridiche Simone, Napoli, 2006.

10. Frković, Snježana, „Republika Hrvatska kao vlasnik nekretnina i pravo građenja“, Hrvatska pravna revija, god. 11., br. 10, 2011.

11. Gavella, Nikola, „Građansko pravo i posebna pravna uređenja za određene vrste dobara“, Zbornik Pravnoga fakulteta u Zagrebu, vol. 62, br. 5-6, 2012.

12. Gavella, Nikola, „O posebnim pravnim uređenjima za pojedine vrste stvari kao sastavnim dijelovima stvarnopravnog uređenja“, Stvarno pravo - posebna pravna uređenja, Narodne novine, Zagreb, 2011.

13. Gavella, Nikola, Stvarno pravo, Informator, Zagreb, 1998.

14. Gillet-Lorenzi, Emmanuelle, Traoré, Seydou, Droit administratif des biens, Centre National de la Fonction Publique Territoriale, Paris, 2007.

15. Gröpl, Christoph, Rupp, Martin, ,State Assets (Public Ownership) in the Federal Republic of Germany“, Ius Publicum Network Review, br. 1, 2011., dostupno na: http://www.ius-publicum.com/repository/uploads/10_03_2011_16_33_Groepl. pdf (11. VII. 2016.).

16. Grubišić, Mihaela, Nušinović, Mustafa, Roje, Gorana, „Prema učinkovitom upravljanju državnom imovinom“, Financijska teorija i praksa, vol. 33, br. 3, 2009.

17. Jelčić, Olga, „Prodaja, zakup i koncesije nekretnina u vlasništvu jedinica lokalne samouprave i Republike Hrvatske“, 12. forum poslovanja nekretninama: zbornik radova, Zagreb, Hrvatska gospodarska komora, 2012., dostupno na: http://www. agenti.hr/sadrzaj/info-agent/strukovni-forumi/forum-12/12-forum-Prodajazakup-koncesije-nekretnina-vlasnistvo-jed-lokalne-samouprave-i-RH.pdf $\quad(11$. VII. 2016.).

18. Josipović, Tatjana, „Posebni pravni režimi na nekretninama“, Nekretnine $u$ pravnom prometu, Inženjerski biro, Zagreb, 2003.

19. Josipović, Tatjana, ,Stvari u vlasništvu države i drugih osoba javnog prava (javno vlasništvo)“, Zbornik Pravnog fakulteta Sveučilišta u Rijeci, vol. 22, br. 1, 2001.

20. Jug, Jadranko, „Posebno stvarnopravno uređenje za vode i vodno dobro“, Stvarno pravo - posebna stvarna uređenja, Narodne novine, Zagreb, 2011. 
21. Krbek, Ivo, Osnovi upravnog prava FNRJ, Jugoslavenska akademija znanosti i umjetnosti, Zagreb, 1950.

22. Krbek, Ivo, Pravo jugoslavenske javne uprave: funkcioniranje i upravni spor, III. knjiga, Birozavod, Zagreb, 1962.

23. Latournerie, Marie-Aimée, „Problématique du droit des propriétés publiques en France“, Zbornik radova Pravnog fakulteta u Splitu, god. 46, br. 1, 2009.

24. Lukačević-Subotić, Željka, „Uređenje instituta koncesije na pojedinim javnim dobrima u zakonodavstvu Republike Hrvatske s posebnim osvrtom na poljoprivredno zemljište u vlasništvu države“, Hrvatska pravna revija, god. 3, br. 3, 2003.

25. Ljubanović, Boris, „Vrednovanje javnih dobara - koncesije na 'kulturnim dobrima' kao 'dobrima od interesa za Republiku Hrvatsku', s posebnim naglaskom na posebnosti tih koncesija“, Zbornik radova Pravnog fakulteta $u$ Splitu, god. 46, br. 1, 2009.

26. Negrut, Vasilica, „Special Domenial Regimes“, Acta Universitatis Danubius: Juridica, vol. 5, br. 1, 2009., dostupno na: http://journals.univ-danubius.ro/ index.php/juridica/article/view/186/177 (11. VII. 2016.).

27. Papier, Hans Jürgen, Recht der Öffentlichen Sachen, Walter de Gruyter, Berlin, 1977.

28. Perkušić, Ante, „Šume i šumska zemljišta - pretvorba prava vlasništva i upis u zemljišne knjige“, Hrvatska pravna revija, god. 4., br. 11, 2004.

29. Ude, Lojze, „Javno dobro“, Socijalno partnerstvo, vol. 22, br. 168-169, 1994.

30. Wolff, Hans J., Bachof, Otto, Stober, Rolf, Verwaltungsrecht, Band 2, Verlag C. H. Beck, München, 2000. 


\section{LEGAL FRAMEWORK FOR USING SOME FORMS OF FINANCIAL PROPERTY IN THE REPUBLIC OF CROATIA}

The aim of this paper is to consider whether the procedures of making giving the use of some properties belonging to the government to interested entrepreneurs and other subjects simple and speedy and whether they ensure the choice of the person who guarantees the carrying out of economic activities of the highest quality within the framework of standards of sustainable development. In this paper attention is focused on properties belonging for the most part to the government and which, according to the assessment of the Croatian public, are not made to full use- agricultural land, forests and forest land and water as a commodity in public use. First considered is whether this property has the capacity to be part of the financial property of the government. Then, modes of regulation are considered and procedure provisions of giving these goods to be used by private persons. Finally, the lack of positive legal regulation is pointed out. This is to encourage the usability of these areas in order to provide suggestions for improving the existing legal framework.

Key words: goods of interest to the Republic of Croatia, agricultural land, forests, forest land, water as commodity, financial property, using public good, Croatia. 